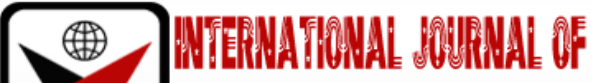

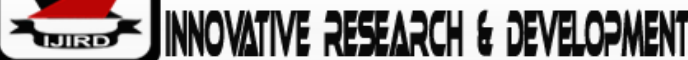

ISSN 2278-0211 (Online)

\section{Design and Construction of an Improved Solar Still for Production of Pure Water}

\begin{tabular}{|c|}
\hline Pius, Joshua \\
Graduate Assistant, Department of Physics, \\
Adamawa State University, Mubi, Nigeria \\
Wilfred, Manliura Amthombata \\
Assistant Lecturer, Department of Physics, \\
Modibbo Adama University, Yola, Nigeria
\end{tabular}

\begin{abstract}
:
Water is a vital natural resource that is needed for the existence and survival of plants and animals on earth. Today fresh water demand is increasing continuously, because of the industrial development but only about 3\% of the world water is potable and this amount is not evenly distributed on the earth. Many parts of the developing countries do not have access to a suitable source of clean drinking water. Most of the sources of water available are from streams, lakes, rivers and sea which cause many diseases because of their impurities. An improved solar still for the production of pure water was design, constructed, and tested for this research work. The system used a separated storage (feed water tank) to collector (distilled water collector tank). Both numerical and experimental methods are used in the analysis for the optimum performance of the system. The result showed that for the period under reviewed (May December, 2015), the average productivity of solar still was 143.99 liters/hour at 213.45 Wm-2 $^{2}$ average daily solar radiation and the overall efficiency of the solar still was $67.15 \%$. This research work has demonstrated that solar water distillation system can be adopted to meet the drinking water need of a typical household and laboratory users.
\end{abstract}

Keywords: Water, solar collector, heat, and distillation

\section{Introduction}

\subsection{Background to the Study}

Water is a vital natural resource that is needed for the existence and survival of plants and animals on earth. It occupies a high percentage of both the earth surface and underground in dynamic and static forms.Areola etal., (1978) stated that, about $67 \%$ of the earth is covered by water. However, the distribution of water across the globe is uneven in terms of quality and quantity, while it is scarce in others.

Today fresh water demand is increasing continuously, because of the industrial development, intensified agriculture, improvement of standard of life and increase of the world population. Only about 3\% of the world water is potable and this amount is not evenly distributed on the earth. On deserts and islands where underground water is not readily obtainable and the cost of shipping the places is high it is worthwhile to take into consideration of producing potable water from saline water, using solar energy that is in abundance in deserts.

Large quantities of fresh water are required in many parts of the world for agricultural, industrial and domestic uses. Lack of fresh water is a prime factor in inhibiting regional economic development. The oceans constitute an inexhaustible source of water but are unfit for human consumption due to their salt content, in the range of $3 \%$ to $5 \%$.In order for it to be used as a healthful fluid for human consumption, water must be free from organism that are capable of causing disease and from mineral substance that could produce adverse physiological effects.

It is also important to ascertain the portability of water before human consumption for health reasons. The nature of the treatment given to water depends upon the kind of impurities that the water contains. Water treatment includes physical, chemical and biological processes that can transform raw water into potable water which is acceptable for human and domestic use.

Energy is one of the most important factors in social and economic development of a country. The amount of energy consumption per capita of a country is a measure of a nation's economic development and it has become an important parameter for sustainable development throughout the world, (Singalet al., 2007).

Renewable energy sources are appropriate solutions of all the possible problems associated with conventional sources of energy. As compared to conventional energy sources, renewable energy sources like, solar, wind, tidal, geothermal energy etc. are renewable by nature and their supply will not be affected by the rate of consumption and are promising for sustainable development. 
Among the renewable energy sources, solar energy is the most promising source due to its quantitative abundance and availability. It plays an essential role in this effort, particularly for domestic and commercial generation of electricity, water heating system and solar distillation system.

Distillation is a physical method of assorting mixtures depending upon the difference in the boiling point of the component substances. The working principle of distillation is to heat a mixture at a specific temperature, collect the hot vapors and condense to separate the component substance. In simpler terms, a highly volatile compound is separated from a less-volatile or non-volatile compound by using distillation. As per evidences, the principle of distillation has been used since ancient times. It is believed that the ancient Arab chemists applied distillation for the first time to separate perfumes.

Today, it is one of the most popular techniques implemented for separation of a mixture and purification of water. Solar distillation systems are appropriate low-cost methodologies to produce drinking water from saline water. Solar distillation process removes impurities such as salts and heavy metals as well as microbiological organisms. Most of the people near coastal areas may face with the unavailability of fresh water due to sea water intrusion into groundwater aquifers.

Medugu and Ndatuwong (2009) studied and constructed a solar still under actual environmental conditions of Mubi, Adamawa State of Nigeria. They performed theoretical analysis of heat and mass transfer mechanisms inside the still and carried out experimental investigations on the distillation performance of the solar still. Their experimental results corresponded favorablywith the theoretical analysis and reported that the productivity of the solar still increased with the intensity of solar radiation and the temperature of feed water.

The solar distillation systems are mainly classified as passive solar still and active solar still (Cornet, 2001). In a passive still the distillation takes place purely by direct sun light. The single slope and double slope solar stills are the conventional low temperature solar stills. They are operating at a temperature below $60^{\circ} \mathrm{C}$. The single slope solar still is more versatile and efficient more than the double slope. In an active solar still, an extra thermal energy is fed to the water in the basin to create a faster rate of evaporation. Further the active solar stills are classified as:

- High temperature distillation solar stills: hot water is fed into the basin from a solar collector panel.

- Pre-heated water application solar stills: hot water is fed into the basin at a constant flow rate.

- Nocturnal production solar stills: hot water is fed into the basin once in a day.

\subsection{Statement of the Problems}

Many parts of the developing countries do not have access to a suitable source of clean drinking water. Most of the water available in streams, lakes, rivers, sea, etc. carries Salts/minerals ( $\mathrm{Na}, \mathrm{Ca}, \mathrm{As}, \mathrm{Fe}, \mathrm{Mn}$ ), Bacteria (E. coli, Cholera, Botulinus), Parasites, Heavy Metals \& total dissolved solid (TDS) (Mendie, 2005).

Some households rely on biomass to heat water and for water purification. In many countries demand for wood is one of the principal contributors to deforestation, (Rasheed, 1995). Others rely on electricity or liquid fuel such as propane for water distillation. The variability of solar energy also limits its usefulness.

The burning or combustion of fossil fuels for heating operations introduces many harmful pollutants into the atmosphere and contributes to environmental problems like global warming and acid rain. Solar energy is an optimum solution as an alternate fuel and absolutely non-polluting, free of cost, and present in huge amount of the earth.

However, as fossil fuel supplies dwindle and cost continues to rise, solar energy should become economically feasible for much application in solar water distillation system. Areas without access to clean water are also usually poverty stricken and do not have the infrastructure necessary to create and support large scale water purification plants (Christopher and Homola, 1990).

Thus, there is a need for a small scale, affordable water purification system for individual families or villages.

\subsection{Aim and Objectives of the Study}

The aim of this study is to design and develop an improved solar still for production of pure water.

The specific objectives are;

- To determine the efficiency of Solar still

- To determine the average production of the solar still

\subsection{Significance of the Study}

This research will be of significant to residential and laboratory users such as drinking, cooking and washing of the laboratory equipment where there is pure water supply problem. Also, to construct a solar still that does not use electricity or fuel but rely on solar energy, using available local materials and labour which are much less expensive and easier to maintain and repair which may be suitable for low-income communities.

\subsection{Justification of the Study}

The increase in the global warming as a result of gases from the fossil fuel and as the fossil fuel supply dwindle and the cost continues to rise in most of the developing countries (Nigeria), to alleviate this problem, a solar still should be designed and constructed. This dissertation aims at the design and construction of an improved solar still for production of pure water for residential and laboratory applications which will be installed in Adamawa State University Mubi. The work will provide sufficient understanding of solar still by allowing a better assessment of the distilling using solar energy. 


\section{Literature Review}

\subsection{History of Solar Distillation System}

Solar energy has been used for many years in obtaining potable water by distillation from contaminated or brackish supplies (Ihalawela\&Careem 2007). As early as 1561, Arabs used solar distillers to obtain drinkable water as well as water-based fragrances. In 1861, the French used solar stills to produce Brandy from wine. In 1872, in Las Salinas, Chile' a solar still made of 64 water basins constructed from wood with sloping glass covers was used to supply water to animals working in the local mines. Even the United States military includes solar stills in their survival kits (Speirs, 2007). Apart from the solar distillation, there are various technologies such as Reverse Osmosis (RO), Electro dialysis (ED), IonExchange (IE), Mechanical Filters (MF) etc. for water purification (Avvannavaret al., 2008). However, energy cost and operational and maintenance cost incurred these methodologies increases the production cost of drinking water. (Rodrígueza and Camachob 1999). Production cost without labor charges is around Rs.150/- to Rs. 500/- per cubic meter by Reverse Osmosis and for other methods the cost may be at same range (Rosemann, 2009).

Use of the solar energy for the distillation of water is one of the appropriate methods to reduce the cost incurred on power when other methodologies are used. The main drawback associated with the solar distillation systems are low distillation efficiency. The solar distiller introduced by the National Engineering Research and Development (NERD) Sri Lanka is a single chamber type and also performing poor distillation efficiency. Therefore, the present experiment was to incorporate a feasible technology to increase the efficiency of the solar distillers. In this experiment the performance efficiency of the $1 \mathrm{~m}^{2}$ size single basin solar distiller manufactured by NERD center was tested, when sand is placed under the black plated corrugated metal sheet that is expected to increase the thermal capacity.

The intensity of solar energy received by the distiller is the single most important parameter affecting the water production (Happer, 2007). To increase the production of a solar distiller, area of the solar distiller or heat conversion efficiency should be increased. However, increase in efficiency is more viable approach than increase in distiller size owing to several reasons including cost of production, handling and fixing (Nwokoye, 2008).

\subsection{Types of Solar Distillation System}

The types of solar distillation system are discussed below,

\subsubsection{Basin Type Solar Distillation System}

It consists of shallow, bracken basin of saline/impure water covered with sloping transparent roof solar water in blackened basin. Thus, evaporating water which gets condensed on the cooler under side of the glass and gets collected as distillate attached to the glass (Sahoo, 2007).

\subsubsection{Wick Type Solar Distillation System}

It consists of a wick instead of a basin. The saline/impure water is passed through the wick or absorbed by the wick at a slow rate by capillary action. A waterproof liner is placed between the insulation and the wick. Solar energy is absorbed by the water in the wick which gets evaporated and later condensed on the underside of the glass and finally collected in the condensate channel fixed on the lower side of the bottom surface (Sahoo, 2007).

\subsection{Methods of Solar Water Purification}

The following are the methods of solar water purification;

\subsubsection{Solar Water Disinfection (SODIS)}

Solar water disinfection is a low technology, simpleprocess of purifying water using solar energy and solar radiation SODIS as a technology. Theprocess involves contaminated water being filled in transparent PET or glass bottles which are thenexposed to the sun for approximately 6 hours. TheUV rays of sun eliminate the diarrhea-causing pathogens, thereby making the water fit forconsumption.

\subsubsection{Solar Water Pasteurization}

Solar water pasteurization involves the use of moderate heat or radiation to kill disease - causing microbes. This heat is provided from cookers that trap solar energy. This method has proven to kill bacteria, viruses, worms and protozoa.

\subsubsection{Solar Water Distillation}

Solar water distillation uses a solar still to condense pure water vapor and settle out harmful substances to make clean, pure drinking water. This process is used when the water is brackish containing harmful bacteria, or for settling out heavy metals and also for desalination of sea water.

\subsection{Energy Requirements for Water Distillation}

The energy required to evaporate water, called the latent heat of vaporization of water, is 2260kilojoules per kilogram $(\mathrm{kJ} / \mathrm{kg}$ ). This means that to produce 1 litre (i.e., $1 \mathrm{~kg}$ as the density of water is $1 \mathrm{~kg} / \mathrm{litre}$ ) of pure water by distilling brackish water requires a heat input of $2260 \mathrm{~kJ}$. This does not allow for the efficiency of the system used which will be less than $100 \%$, or for any recovery of latent heat that is rejected when the water vapour is condensed. 
It should be noted that, although $2260 \mathrm{~kJ} / \mathrm{kg}$ is required to evaporate water, to pump a $1 \mathrm{~kg}$ of water through $20 \mathrm{~m}$ head requires only $0.2 \mathrm{~kJ} / \mathrm{kg}$. Distillation is therefore normally considered only where there is no local source of fresh water that can be easily pumped or lifted.

\subsection{Thermal Efficiency}

In thermodynamics, the thermal efficiency $\left(\eta_{t h}\right)$ is a dimensionless performance measure of a device that uses thermal energy, such as an internal combustion engine, a steam turbine or a steam engine, a boiler, a furnace, or a refrigerator for example. In other words, efficiency indicates how well an energy conversion or transfer process is accomplished.

In general, energy conversion efficiency is the ratio between the useful output of a device and the input, in energy terms. For thermal efficiency, the input, $Q_{i n}$, to the device is heat, or the heat-content of a fuel that is consumed. The desired output is mechanical work, $W_{\text {out }}$, or heat, $Q_{o u t}$, or possibly both. Because the input heat normally has a real financial cost, a memorable, generic definition of thermal efficiency is (Howell \&Buckius, 1987).

Thermal efficiency $\eta_{\text {th }}=\frac{\text { Output }}{\text { Input }}$

Where

Output = is the mechanical work, $W_{\text {out }}$ or heat, $Q_{\text {out }}$

Input $=$ is the heat, $Q_{\text {in }}$ or the heat- content that is consumed

From the first law of thermodynamics, the energy output cannot exceed the input, so

$0 \leq \eta_{t h} \leq 1$

When expressed as a percentage, the thermal efficiency must be between $0 \%$ and $100 \%$.

Thermal efficiency $\eta_{\text {th }}=\frac{\text { Output }}{\text { Input }} \times 100$

Equation 2.2 can also be express as

Thermal efficiency $\eta_{\text {th }}=\frac{\Delta \mathrm{W}_{\text {out }}}{\mathrm{Q}_{\mathrm{H}}} \times 100$

But $\Delta W_{\text {out }}=Q_{H}-Q_{C}$

Hence, the equation 2.3 becomes

Thermal efficiency $\eta_{\text {th }}=\frac{Q_{H}-Q_{C}}{Q_{H}} \times 100$

Where,

$Q_{H}=$ Heat consumed or absorbed

$Q_{C}=$ Heat lost

In terms of temperature the equation 2.4 can be as follows

Thermal efficiency $\eta_{\text {th }}=\frac{T_{\text {out }}-T_{\text {in }}}{T_{\text {out }}} \times 100$

Where

$T_{\text {out }}=$ Temperature of the hot water going out of the solar collector panel

$T_{i n}=$ Temperature of the cold water entering the solar collector panel

Efficiency is typically less than $100 \%$ because there are inefficiencies such as friction and heat loss that convert the energy into alternative forms. For example, a typical gasoline automobile engine operates at around $25 \%$ efficiency, and a large coal-fueled electrical generating plant peak at about $46 \%$. The largest diesel engine in the world peaks at 51.7\%. In a combined cycle plant, thermal efficiencies are approaching 60\% (Holman, 1980). Such a real-world value may be use as a figure of merit for the device.

For engines where a fuel is burned, there are two types of thermal efficiency: indicated thermal efficiency and brake thermal efficiency (Charles, 1985). This efficiency is only appropriate when comparing similar types or similar devices. For other systems, the specifics of the calculations of efficiency vary but the non-dimensional input is still the same. Efficiency = Output energy / input energy.

\subsection{Heat Transfer in Active Solar Distillation System}

The heat transfer in solar still is mainly classified into internal and external heat transfer (Feilizadehet al., 2010).

\subsubsection{Internal Heat Transfer}

The internal heat transfer occurs within the solar still from water surface to inner surface of the glass cover, which mainly consists of evaporation, convection and radiation. The convective and evaporative heat transfers take place simultaneously and are independent of radiative heat transfer (Sampathkumaret al., 2010).

\subsubsection{Radiative Heat Transfer}

The view factor is considered as unity because of glass cover inclination is small in the solar still. The rate of radiative heat transfer between water to glass is given by,

$q_{r, w-g}=h_{r, w-g}\left(T_{w}-T_{g i}\right)$

Where

$q_{r, w-g}=$ rate of radiative heat transfer from water to glass cover $\left(\mathrm{W} / \mathrm{m}^{2}\right)$

$h_{r, w-g}=$ radiative heat transfer coefficient from water to glass cover $\left(\mathrm{W} / \mathrm{m}^{2}{ }^{0} \mathrm{C}\right)$

$T_{w}=$ water temperature $\left({ }^{\circ} \mathrm{C}\right)$

$T_{g i}=$ inner surface glass cover temperature $\left({ }^{0} \mathrm{C}\right)$ 
The radiative heat transfer coefficient between water to glass is given as,

$h_{r, w-g}=\varepsilon_{f f} \sigma\left[\frac{\left(T_{w}+273\right)^{2}+\left(T_{g i}+273\right)^{2}}{T_{w}+T_{g i}+546}\right] W m^{-2} K^{-1}$

Where,

$\varepsilon_{f f}=$ effective

$\sigma=$ Stefan Boltzmann constant $\left(5.67 \times 10^{-8} \mathrm{Wm}^{-2} \mathrm{~K}^{4}\right)$

The effective emittance between water to glass cover is presented as,

$\varepsilon_{f f}=\left[\frac{1}{\left(\frac{1}{\varepsilon_{g}}\right)+\left(\frac{1}{\varepsilon_{W}}\right)-1}\right]$

Where,

$\varepsilon_{g}=$ emissivity of glass

$\varepsilon_{w}=$ emissivity of water

\subsubsection{Convective Heat Transfer}

Natural convection takes place across the humid air inside the basin due to the temperature difference between the water surfaces to inner surface of the glass cover. The rate of convective heat transfer between water to glass is given by (Velmurugan\&Srithar, 2007),

$q_{c, w-g}=h_{c, w-g}\left(T_{w}-T_{g i}\right)$

Where

$q_{c, w-g}=$ rate of convective heat transfer from water to glass cover $\left(\mathrm{W} / \mathrm{m}^{2}\right)$

$h_{c, w-g}=$ convective heat transfer coefficient from water to glass cover $\left(\mathrm{W} / \mathrm{m}^{20} \mathrm{C}\right)$

The convective heat transfer coefficient depends on the temperature difference between evaporating and condensing surface, physical properties of fluid, flow characteristic and condensing cover geometry. The various models were developed to find the convective heat transfer coefficient. One of the oldest methods was developed by (Dunkle, 1961) and his expressions have certain limitations, which are listed below.

- Valid only for normal operating temperature $=50^{\circ} \mathrm{C}$ in a solar still and equivalent temperature difference of $\Delta \mathrm{T}$ $=17^{\circ} \mathrm{C}$.

- This is independent of cavity volume, i.e., the average spacing between the condensing and evaporating surfaces.

- This is valid only for upward heat flow in horizontal enclosed air space, i.e., for parallel evaporative and condensing surfaces.

The convective heat transfer coefficient is expressed as,

$h_{c, w-g}=0.008\left[\Delta T^{\prime}\right]^{\frac{1}{3}} W m^{-2} K^{-1}$

Where $\Delta T^{\prime}=\left(T_{w}-T_{g i}\right)+\frac{\left(P_{w}-P_{g i}\right)+\left(P_{w}+273\right)}{268.9 \times 10^{-3}-P_{w}}$

$P_{w}=\exp ^{\left[25.317-\left(\frac{5144}{273+T_{w}}\right)\right]}$

$P_{g i}=\exp \left[25.317-\left(\frac{5144}{273+T g}\right)\right]$

Where

$P_{w}=$ partial vapour pressure at water temperature $\left(\mathrm{N} / \mathrm{m}^{2}\right)$

$P_{g i}=$ partial vapour pressure at inner surface glass temperature $\left(\mathrm{N} / \mathrm{m}^{2}\right)$

\subsubsection{Evaporative Heat Transfer}

The performance of solar still depends on the evaporative and convective heat transfer coefficients. Many researchers developed mathematical relations to evaluate the evaporative and convective heat transfer coefficients. The general equation for the rate of evaporative heat transfer between water to glass is given by (Tiwari et al., 2007),

$q_{e, w-g}=h_{e, w-g}\left(T_{w}-T_{g i}\right)$

Where,

$q_{e, w-g}=$ rate of evaporative heat transfer from water to glass cover $\left(\mathrm{W} / \mathrm{m}^{2}\right)$

$h_{e, w-g}=$ evaporative heat transfer coefficient from water to glass cover $\left(\mathrm{W} / \mathrm{m}^{20} \mathrm{C}\right)$

The evaporation takes place inside the solar still by addition of heat in the water by means of solar radiation. Dunkle (1961) developed a model to evaluate the evaporative heat transfer coefficient as follows:

$h_{e, w-g}=0.013 h_{c, w-g}$

The total heat transfer coefficient of water to glass is defined as

$h_{t, w-g}=h_{c, w-g}+h_{e, w-g}+h_{r, w-g}$

The rate of heat transfer of water to glass is defined as

$q_{t, w-g}=q_{c, w-g}+q_{e, w-g}+q_{r, w-g}$ 


\subsubsection{External Heat Transfer}

The external heat transfer in solar still is mainly governed by conduction, convection and radiation processes, which are independent each other. The external heat transfer coefficient depends on the position as follow

\subsubsection{Top Loss Heat Transfer Coefficient}

The heat is lost from outer surface of the glass to atmosphere through convection and radiation modes. The glass and atmospheric temperatures are directly related to the performance of the solar still. So, top loss is to be considered for the performance analysis. The temperature of the glass cover is assumed to be uniform because of small thickness. The total top loss heat transfer coefficient is defined as (Omar \&Mazen, 2007),

$h_{t, g-a}=h_{r, g-a}+h_{c, g-a}$

$q_{t, g-a}=q_{r, g-a}+q_{c, g-a}$

$q_{t, g-a}=h_{t, g-a}\left(T_{g o}-T_{a}\right)$

Where,

$q_{t, g-a}=$ rate of total heat transfer from glass cover to ambient $\left(\mathrm{W} / \mathrm{m}^{2}\right)$

$q_{r, g-a}=$ rate of radiative heat transfer from glass cover to ambient $\left(\mathrm{W} / \mathrm{m}^{2}\right)$

$q_{c, g-a}=$ rate of convective heat transfer from glass cover to ambient $\left(\mathrm{W} / \mathrm{m}^{2}\right)$

$T_{g o}=$ outer surface glass cover temperature $\left({ }^{\circ} \mathrm{C}\right)$

$T_{a}=$ ambient temperature $\left({ }^{\circ} \mathrm{C}\right)$

$h_{t, g-a}=$ total (convective and radiative) heat transfer coefficient from glass cover to ambient $\left(\mathrm{W} / \mathrm{m}^{20} \mathrm{C}\right.$ )

The radiative heat transfer between glass to atmosphere is given by (Omar \&Mazen, 2007),

$q_{r, g-a}=h_{r, g-a}\left(T_{g o}-T_{a}\right)$

The radiative heat transfer coefficient between glass to atmosphere is given as,

$h_{r, g-a}=\varepsilon_{g} \sigma\left[\frac{\left(T_{g o}+273\right)^{4}-\left(T_{s k y}+273\right)^{4}}{T_{g o}-T_{a m b}}\right]$

Where $T_{\text {sky }}=T_{a}-6$

Where

$T_{\text {sky }}=$ temperature of sky $\left({ }^{\circ} \mathrm{C}\right)$

The convective heat transfer between glass to atmosphere is given by (Omar and Mazen, 2007),

$q_{c, g-a}=h_{c, g-a}\left(T_{g o}-T_{a m b}\right)$ and the convective heat transfer coefficient between glasses to atmosphere is given by,

$h_{c, g-a}=2.8+(3.0 \times V)$

Where $V=$ wind velocity $(\mathrm{m} / \mathrm{s})$

The total internal heat loss coefficient $\left(h_{t, w-g}\right)$ and conductive heat transfer coefficient of the glass $\left(\frac{K_{g}}{K_{a}}\right)$ is expressed as

$U_{w o}=\frac{1}{h_{t, w-g}}+\left(\frac{L_{g}}{K_{a}}\right)$

Where,

$K_{g}=$ thermal conductivity of glass cover $\left(\mathrm{Wm}^{-10} \mathrm{C}\right)$

$L_{a}=$ thickness of insulation glass cover (m)

The overall top loss coefficient $C$ ) from the water surface to the ambient through the glass cover is

$U_{t}=\frac{h_{t, w-g} \times h_{t, g-a}}{h_{t, g-a}+U_{w o}}$

\subsubsection{Efficiency Calculation}

The overall efficiency of solar still can be obtain by

$\eta=\left[\frac{Q L}{H \times A_{S} \times 3600}\right] \times 100 \%$

$\eta=$ efficiency of the solar still (\%)

$\mathrm{Q}=$ productivity of the solar still (lit $/ \mathrm{hr}$ )

$\mathrm{L}=$ constant for latent heat of vaporization of water $(2260 \mathrm{~kJ} / \mathrm{kg})$

$\mathrm{H}=$ hourly solar radiation $\left(\mathrm{Wm}^{-2}\right)$

$\mathrm{A}_{\mathrm{s}}=$ area of basin in solar still $\left(\mathrm{m}^{2}\right)$

\subsection{The Basic Principle of Solar Heating}

The conversion process of solar energy is the conversion of sunlight into heat. Any dark colored surface that faces the sunlight is a solar heat collector. The dark surface becomes hot when it has absorbed some light energy and converts it's to heat instead of reflecting the light.

Considering solar distillation system for example, when the rays of sunlight that falls on the reflector are reflected into the basin line chamber through a transparent cover glass. The absorber plate in this case aluminum sheet, convert the rays into the longer wavelength, heat energy that radiate from the interior surface. Most of this radiate energy, because of its long wavelength cannot be radiate out through the glass and it is therefore trapped within the enclosed chamber. As a result of this, the temperature of basin line chamber increases continuously.

During rainy season/winter a dark colored object is very inefficient to serve as a solar collector when the surrounding air is cold. Water distillation with solar energy is not easy because the process of harnessing solar radiation is 
difficult because the solar energy that reaches the earth is scattered over a large area. Hence, this sun does not deliver that much energy at any particular time due to the process known as diffuse radiation.

Therefore, solar collector does three (3) things; allowing sunlight inside the glass, trapping most of the heat inside and absorbing the sunlight and change it into heat (Walker, 2007).

\subsubsection{Concentrating Sunlight}

Some device, such as mirror or some type of reflective metal is use to concentrate light and heat from the sun into a small distil chamber making the energy more concentrated and therefore more potent (Walker, 2007).

\subsubsection{Converting Light to Heat}

Any black surface on the inside of water distillation system, will improve the effectiveness of turning light into heat. A black paint will absorb almost all of the sun's light and turn it into heat, substantially improving the effectiveness of the distillation chamber. Also, the better a paint conduct heat, the faster the distillation systems work (Walker, 2007).

\subsubsection{Trapping of Heat}

Isolating the air inside the system chamber from the air outside the system makes an important difference. Using a clear solid, like a plastic bag or a glass cover will trap the heat inside using the greenhouse effect. This makes it possible to reach similar temperature on cold and windy days as on hot days (Walker, 2007).

\section{Materials and Method}

\subsection{Materials}

Materials used for the construction are:

- Plywood

- Transparent Glass

- Reflecting Mirror

- Black paint

- Metal sheet Aluminum sheet

- Thermocouple

- Metal pipes or aluminum pipe

- Header pipes

- Top gum

- Screws drivers, bolts and nut

- Wood

- PVC gum

- Saw dust

- Tanks

- Nails

- three-quarter rubber pipe

- Agbro gum

- Five minutes araldite

- Thermometer

- Measuring tape

\subsection{Methods}

\subsubsection{System Description}

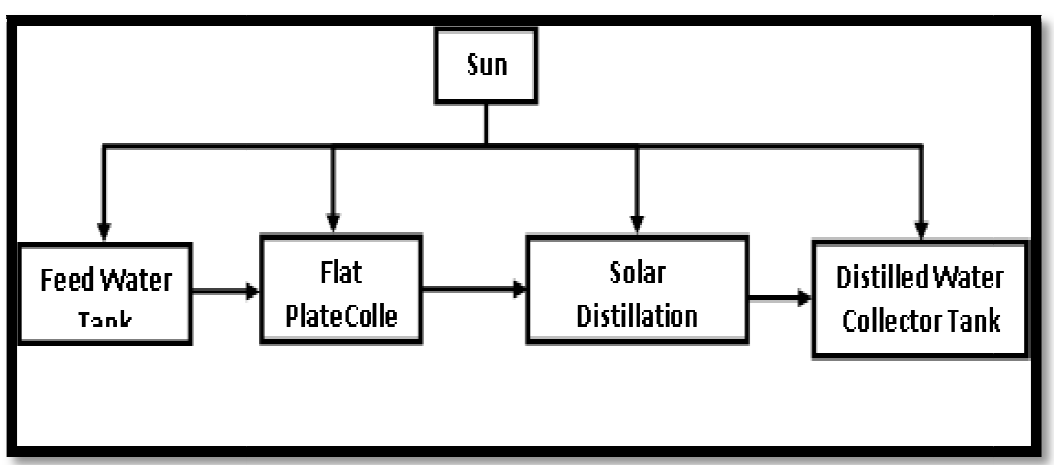

Figure 1: The Block Diagram of the Improved Solar Still System 
An active system of solar water distillation was selected as the bases for the design in this research work. It does not require electricity but rely on the solar energy. In this system an extra thermal energy (solar collector) produces hot water that is fed into the basin from a solar collector panel to create a faster rate of evaporation.

The parabolic trough coupled with the collector panel serves the purpose of solar water heating system which uses solar collector panel to capture the suns radiation and convert it into heat in the form of hot water. The collector panel is painted black to improve absorption of the sun rays and is placed in between the parabolic trough that is coated with plane mirrors to increase the temperature heating the tubes. The water that flows through the tubes becomes hot and moves to the distillation chamber for distillation proper.

The trapezoidal shaped solar distillation system box and the parabolic trough are tilted to an angle equal to the latitudes of Mubi $\left(10^{0} 15^{I}\right)$ to ensure that maximum irradiance falls on the solar collector facing southwards.

Water to be distilled is poured into the still chamber which partially fills the chamber from the solar collector panel. The transparent glass cover of the distillation system allows the solar radiation to pass into the interior surface with a blackened painted material (aluminum sheet) to improve absorption of the sun rays.

The water begins to heat up and the moisture content of the air trapped between the water surface and the glass cover increases. The heated water vapor that evaporates from the basin condenses on the inside of the glass cover. In this process, the salts and microbes that were in the original water are left behind. Condensed water trickle down the inclined glass cover to an interior collection trough and out to a distilled water collector tank.

\subsubsection{System Design}

The constructed still box was designed by considering the length (l), breadth (b) and the depth (d) of the still box. The length is $0.93 \mathrm{~m}$, the breadth is $0.70 \mathrm{~m}$ and the depth is $0.40 \mathrm{~m}$, hence the volume of the box can be obtained using the expression

$\mathrm{V}=\mathrm{lbd}$

$\mathrm{V}=0.93 \times 0.70 \times 0.40$

$\mathrm{V}=0.2604 \mathrm{~m}^{3}$

Hence, the volume of the still box can contain 260 liters of water.

The constructed parabolic trough was designed by considering the number of liter(s) of water that you want to pass through the solar collector panel. The solar collector panel is made of copper tube of diameter $0.01 \mathrm{~m}$, and then the radius (r) of the tube is $0.005 \mathrm{~m}$. Two (2) liters of water was considered for this work then the volume (V) of the tube is $0.002 \mathrm{~m}^{3}$. The required length for the construction can be calculated using the expression

$\mathrm{L}=\frac{\mathrm{V}}{\pi \mathrm{r}^{2}}$

$\mathrm{L}=\frac{0.002}{3.142 \times 0.005^{2}}$

$\mathrm{L}=2.52 \mathrm{~m}$

\subsection{System Construction}

\subsubsection{Construction of the Still Box}

The box was constructed in the shape of cuboid/trapezoid. The cuboid shape is the most outer most component of the system which is made by plywood, because is very cheap, can be cut into numerous forms by grooving and its surface can be made smooth and easily join together.

The plywood was placed on the marking table and it was marked out to the required dimension $0.75 \mathrm{~m} \mathrm{x} 0.93 \mathrm{~m} \mathrm{x}$ $0.43 \mathrm{~m}$ for the cuboid shape and $0.75 \mathrm{~m} \times 0.93 \mathrm{~m} \times 0.43 \mathrm{~m}$ for the trapezoid shaped box. Hack saw blade was used to cut out to the required dimension. The cut-out plywood was assembled together with nails, and then top bond mixed with saw dust serves as a binder was poured inside the assembled shape as shown in Figure 2

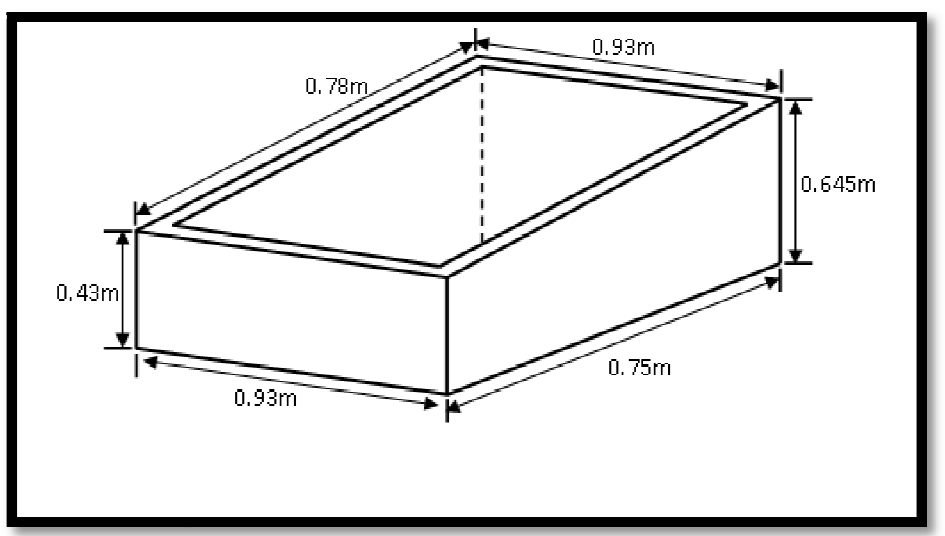

Figure 2: The Solar Still Box 


\subsubsection{Construction of Solar Still Collector Box}

The aluminum sheet was used and was placed on a construction table and was marked out carefully to a dimension $0.70 \mathrm{~m} \times 0.88 \mathrm{~m} \times 0.40 \mathrm{~m}$. This dimension was cut out using a metal scissors and was folded into cuboid shape. The shape between the sheets and the plywood was filled with the saw dust and this serves as an insulator, as shown in the Figure 3

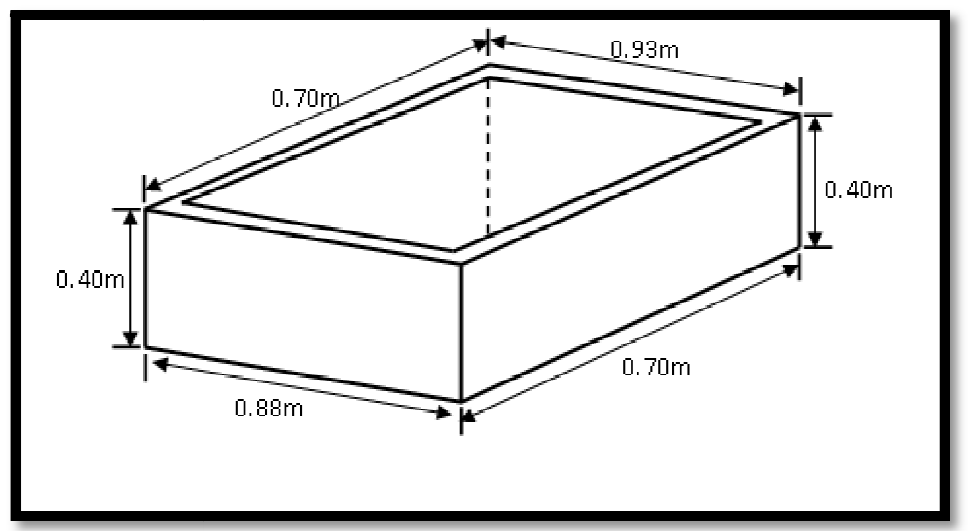

Figure 3: The Solar Still Collector Box

\subsubsection{Construction of the Channel}

The material used for the construction is aluminum sheet. The condensate that is formed slides over the inclined to glass cover and falls in the passage, this passage fetches out the pure water, as shown in the Figure 4

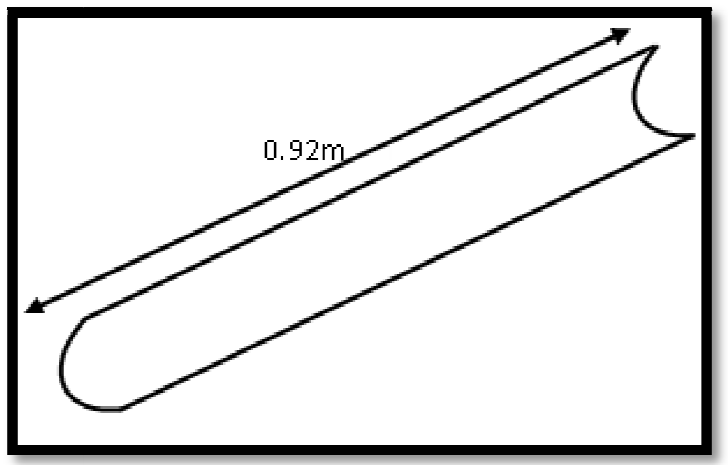

Figure 4: The Channel

\subsubsection{Construction of the Transparent Top Glass Cover}

The plane glass was marked out to a required dimension $0.76 \mathrm{~m} \times 0.91 \mathrm{~m}$ as in Figure 5. A diamond glass cutter was used to cut the glass. The plane glass was placed on top of the trapezoid shaped box. It had to be clean in order to let in some sunlight and hold in heat. The glass is choosing because it is highly transparent and not easily damage and it has to be $0.04 \mathrm{~m}$ thick or more to reduce breakage

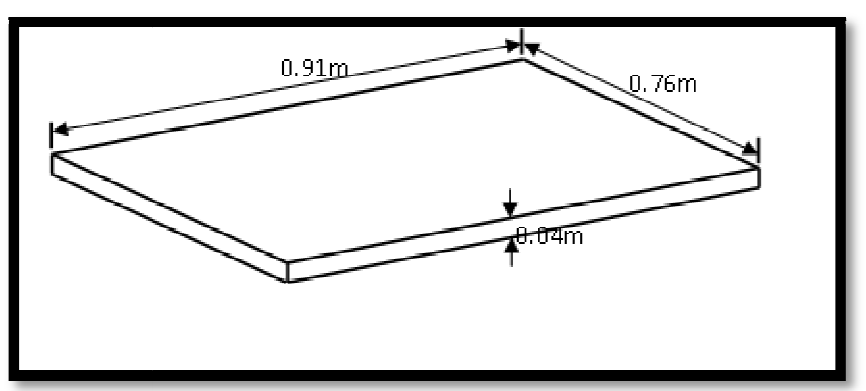

Figure 5: The Transparent Top Glass Cover

\subsubsection{Construction of the Parabolic Trough}

Metal sheet was used in the construction of parabolic trough. The sheet was placed and marked out to a required dimension $0.13 \mathrm{~m} \times 1.23 \mathrm{~m}$. Then hack saw blade was used in cutting the metal sheet to obtain five (5) pieces slides. The reflecting mirror was also cut to the same dimension. The metal sheet was wielded together to form the parabolic shape and the four pieces of the reflecting mirror gummed with the welded metal sheet.

Two metal rods of length $0.50 \mathrm{~m}$ and $0.85 \mathrm{~m}$ and radius of $0.15 \mathrm{~m}$ were cut welded to the parabolic trough to tilt it and $1.20 \mathrm{~m}$ rod with radius $0.6 \mathrm{~m}$ were cut and welded to the trough which serves as stand as shown in Figure 6 


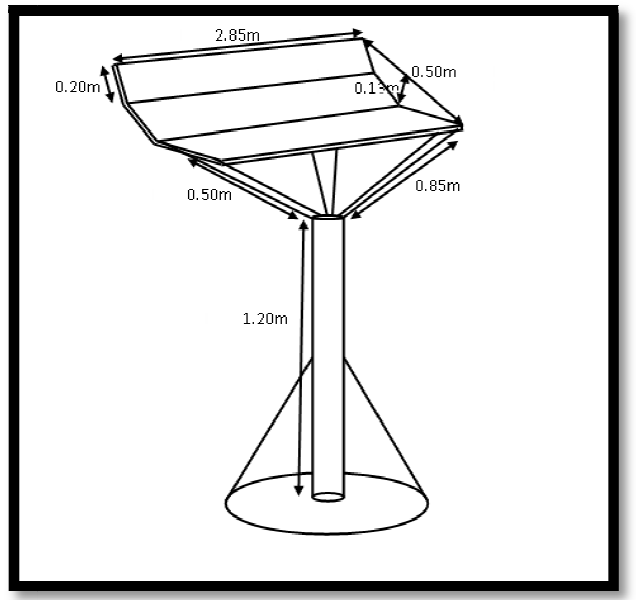

Figure 6: The Parabolic Trough

\subsubsection{Construction of the Solar Collector Panel}

Copper tube of diameter $0.05 \mathrm{~m}$ and length $2.520 \mathrm{~m}$ was used for the construction of the collector panel which serves as solar heating system to capture the suns radiation and convert it into useful heat in the form of hot water. The copper tube was place in between the parabolic trough welded by two metal rods of $0.10 \mathrm{~m}$ length to the parabolic trough as shown in Figure 7

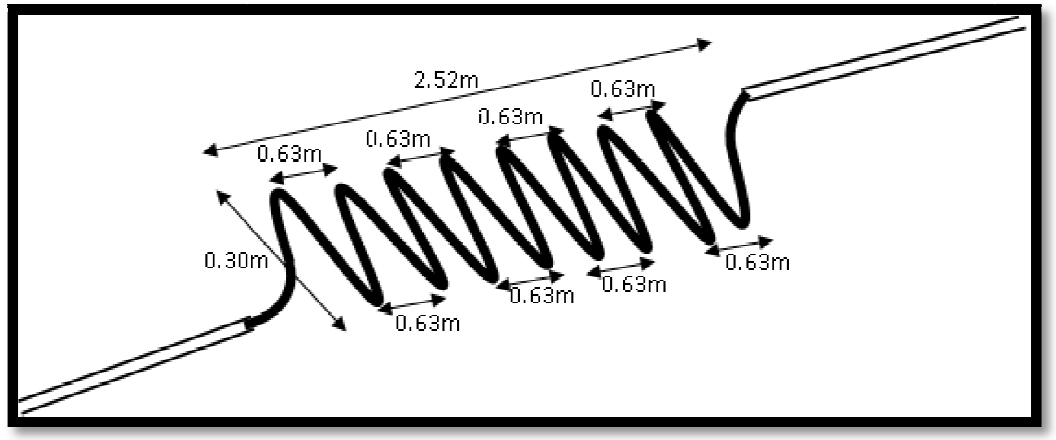

Figure 7: The Solar Collector Panel

\subsubsection{Assembled design of the Solar Still}

The configuration of the design and constructed solar water distillation system coupled with the solar collector panel and the two tanks (i.e., distilled water collector tank and feed water tank).

The feed water tank of 100 liters capacity mounted on a metal stand of about $2.13 \mathrm{~m}$ above the ground and $0.6 \mathrm{~m}$ above the parabolic trough so that the gravity will pull cold water from the tank to the solar collector panel. A half-inch garden horse and three-quarter rubber was used to connect the outlet of the tank. The valve A of the tank allows the flow of water. The outlet of the solar collector panel called valve B is connected to the feed water inlet of then still with half-inch garden horse and half-inch metal pipe.

The distilled water collector tank was mounted on a $0.6 \mathrm{~m}$ metal stand and it has the capacity of 10 liters. The connection of the outlet of distilled water collector tank is connected with a half-inch garden horse and half-inch metal pipe. PVC gum and saw dust were used to connect all the pipes to prevent leakage of water.

The feed water tank has a tap that controls the flow of water into the solar collector panel. The solar collector panel has two valves A and B to control the flow of water from the feed water tank and to the still chamber respectively. At the outlet of distilled water collector tank, a half-inch tap is located the lower end of the tank that allows the collection of the distilled water for use.

The blackened copper tubes of the solar collector panel absorbs both the direct and diffuse solar radiation that falls on it and convert it into heat energy which heat up the water in the tubes then this causes the density of water inside the tube lighter.

Water from the feed water tank is cooler and heavier and by gravity it pulls and pushes the lighter water through the gate valve A where the water stays for 3 minutes then to the solar distillation chamber through the gate valve B for distillation proper.

The plane mirrors refract all the direct and diffused solar radiation into and onto the blackened surface (aluminum sheet). The hot water from the collector panel increases the temperature of the water in the still chamber which increases the rate of evaporation. Condensed water tricks down the inclined glass to an interior collector trough and out to a distilled water collector tank for use as shown in Figure 8 


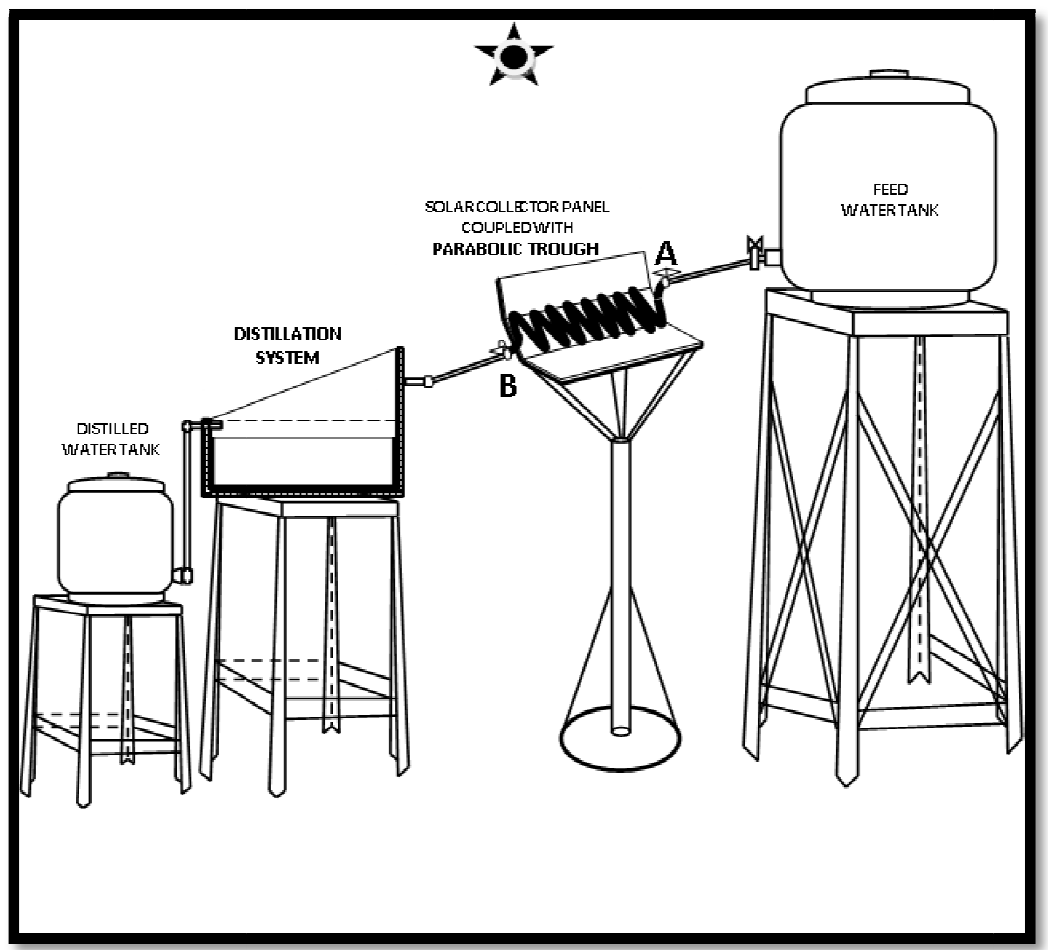

Figure 8: Assembled Design of Solar Still with the Solar Collector Panel

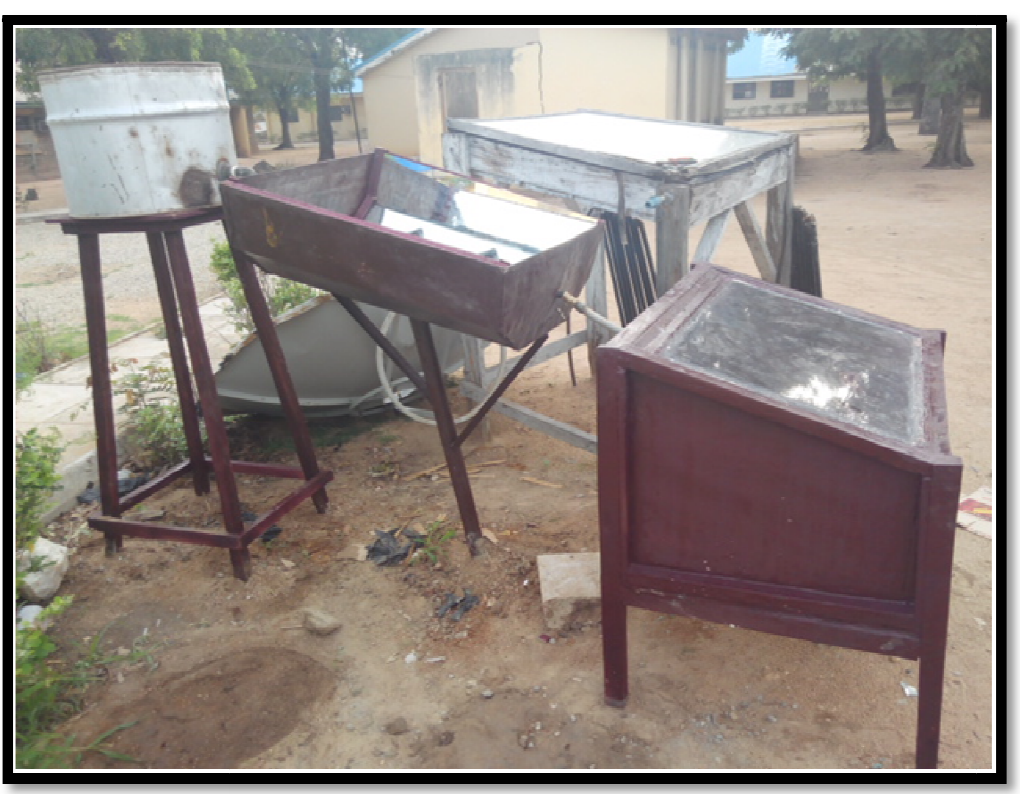

Figure 9: Assembled Solar Still with the Collector Panel

\section{Data Presentation, Analysis and Discussion of Results}

\subsection{Data Presentation, Analysis and Results}

The performance of the still was measured at Adamawa State University Mubi, Adamawa State Nigeria by measuring the temperature of water from collector tank and solar collector water temperature were recorded with the help of thermometers. Tilt angle of glazing adjusted $10^{0} 15^{\mathrm{I}}$ with angle finder. The ambient temperature and the solar radiation data with respect to the location was collected from Adamawa State University meteorological station.

The improved solar technology produces the safe quality drinking water as other distillation technologies, only that the energy source is different (solar) for producing clean drinking water. The amount of distillate depends on the design of the still, intensity of solar radiation and atmospheric condition in the surrounding (Medugu\&Malgwi, 2006).

The solar still was filled up to $0.25 \mathrm{~m}$ depths with volume $0.25 \mathrm{~m}^{3}$. Productivity of the still (litres/hour) was measured by using calibrated jar. Overall efficiency of the solar still and solar collector panel was then calculated using equations 2.20 and 2.5 .

The data were recorded for eight months and were taken at one hour interval from 7am to 6pm for the working days of every month (May to December) at Adamawa State University Mubi, Adamawa State Nigeria. A working day used represented the specific day of the month for which the extraterrestrial radiation value was estimated to be the closest as the whole month average (Duffie\& Beckman, 1999). The working days for May, June, July, August, September, October, 
November and December were 11 th -15 th, 8 th -12 th, 6 th -10 th, 10 th -14 th, 7 th -11 th, 12 th -16 th, 9 th -13 th and 7 th - 11 th respectively.

\begin{tabular}{|c|c|c|c|}
\hline \multicolumn{4}{|c|}{ MAY } \\
\hline Time(hr) & $\mathrm{T}_{\mathrm{go}}\left({ }^{0} \mathrm{C}\right)$ & $\mathrm{T}_{\mathrm{gi}}\left({ }^{0} \mathrm{C}\right)$ & $\mathrm{T}_{\mathrm{w}}\left({ }^{0} \mathrm{C}\right)$ \\
\hline 07:00 & 20.35 & 21.45 & 38.80 \\
\hline 08:00 & 29.10 & 30.70 & 50.15 \\
\hline 09:00 & 30.45 & 32.65 & 55.95 \\
\hline $10: 00$ & 32.95 & 34.85 & 70.40 \\
\hline $11: 00$ & 35.00 & 38.40 & 73.10 \\
\hline $12: 00$ & 35.85 & 41.00 & 79.05 \\
\hline $13: 00$ & 37.95 & 46.15 & 83.00 \\
\hline $14: 00$ & 59.00 & 70.00 & 86.25 \\
\hline $15: 00$ & 60.75 & 68.95 & 94.35 \\
\hline $16: 00$ & 57.45 & 61.30 & 90.90 \\
\hline $17: 00$ & 50.85 & 58.10 & 84.95 \\
\hline 18:00 & 45.05 & 50.45 & 79.40 \\
\hline \multicolumn{4}{|c|}{ JUNE } \\
\hline Time(hr) & $\mathrm{T}_{\mathrm{go}}\left({ }^{\circ} \mathrm{C}\right)$ & $\mathrm{T}_{\mathrm{gi}}\left({ }^{\circ} \mathrm{C}\right)$ & $\mathrm{T}_{\mathrm{w}}\left({ }^{0} \mathrm{C}\right)$ \\
\hline 07:00 & 21.85 & 23.40 & 34.85 \\
\hline 08:00 & 24.60 & 27.00 & 39.40 \\
\hline 09:00 & 28.95 & 31.90 & 48.15 \\
\hline $10: 00$ & 31.05 & 37.65 & 57.45 \\
\hline 11:00 & 34.85 & 40.15 & 65.05 \\
\hline $12: 00$ & 38.00 & 44.00 & 70.85 \\
\hline $13: 00$ & 43.15 & 49.75 & 77.40 \\
\hline $14: 00$ & 49.05 & 56.00 & 81.00 \\
\hline $15: 00$ & 53.40 & 63.10 & 86.15 \\
\hline $16: 00$ & 68.90 & 78.00 & 90.00 \\
\hline $17: 00$ & 61.45 & 74.05 & 84.10 \\
\hline 18:00 & 51.00 & 70.90 & 73.00 \\
\hline \multicolumn{4}{|c|}{ JULY } \\
\hline Time(hr) & $\mathrm{T}_{\mathrm{go}}\left({ }^{\circ} \mathrm{C}\right)$ & $\left.\mathrm{T}_{\mathrm{gi}}{ }^{0} \mathrm{C}\right)$ & $\mathrm{T}_{\mathrm{w}}\left({ }^{\circ} \mathrm{C}\right)$ \\
\hline 07:00 & 19.85 & 22.40 & 29.35 \\
\hline 08:00 & 20.45 & 24.75 & 32.05 \\
\hline 09:00 & 24.75 & 29.00 & 37.00 \\
\hline $10: 00$ & 28.00 & 34.80 & 41.75 \\
\hline $11: 00$ & 32.35 & 38.15 & 49.00 \\
\hline $12: 00$ & 37.05 & 43.00 & 58.65 \\
\hline $13: 00$ & 44.00 & 49.15 & 60.95 \\
\hline $14: 00$ & 49.80 & 55.00 & 64.75 \\
\hline $15: 00$ & 56.15 & 58.85 & 73.00 \\
\hline $16: 00$ & 52.85 & 59.00 & 70.05 \\
\hline $17: 00$ & 50.40 & 59.45 & 65.95 \\
\hline $18: 00$ & 45.00 & 50.05 & 60.75 \\
\hline \multicolumn{4}{|c|}{ AUGUST } \\
\hline Time(hr) & $\mathrm{T}_{\mathrm{go}}\left({ }^{\mathrm{O}} \mathrm{C}\right)$ & $\mathrm{T}_{\mathrm{gi}}\left({ }^{0} \mathrm{C}\right)$ & $\mathrm{T}_{\mathrm{w}}\left({ }^{\circ} \mathrm{C}\right)$ \\
\hline 07:00 & 18.75 & 19.00 & 28.05 \\
\hline 08:00 & 19.80 & 21.75 & 31.87 \\
\hline 09:00 & 22.40 & 25.00 & 35.05 \\
\hline $10: 00$ & 27.45 & 29.90 & 38.75 \\
\hline 11:00 & 30.00 & 35.00 & 46.85 \\
\hline $12: 00$ & 36.75 & 39.05 & 50.40 \\
\hline $13: 00$ & 41.85 & 46.00 & 58.80 \\
\hline $14: 00$ & 47.00 & 51.75 & 60.00 \\
\hline $15: 00$ & 49.95 & 53.80 & 68.50 \\
\hline $16: 00$ & 50.90 & 58.00 & 65.05 \\
\hline $17: 00$ & 48.70 & 54.05 & 60.00 \\
\hline $18: 00$ & 44.05 & 50.45 & 58.95 \\
\hline
\end{tabular}




\begin{tabular}{|c|c|c|c|}
\hline \multirow{2}{*}{\multicolumn{4}{|c|}{ SEPTEMBER }} \\
\hline & & & \\
\hline Time(hr) & $\mathrm{T}_{\mathrm{go}}\left({ }^{0} \mathrm{C}\right)$ & $\mathrm{T}_{\mathrm{gi}}\left({ }^{0} \mathrm{C}\right)$ & $T_{w}\left({ }^{0} \mathrm{C}\right)$ \\
\hline 07:00 & 17.65 & 19.00 & 21.95 \\
\hline 08:00 & 19.95 & 22.05 & 24.70 \\
\hline 09:00 & 22.45 & 24.75 & 29.05 \\
\hline $10: 00$ & 26.95 & 28.85 & 33.85 \\
\hline $11: 00$ & 30.05 & 34.05 & 38.95 \\
\hline $12: 00$ & 36.00 & 39.85 & 45.05 \\
\hline $13: 00$ & 39.65 & 42.00 & 59.70 \\
\hline $14: 00$ & 47.00 & 49.95 & 63.05 \\
\hline $15: 00$ & 53.95 & 57.00 & 69.00 \\
\hline $16: 00$ & 57.00 & 63.95 & 70.80 \\
\hline $17: 00$ & 54.75 & 60.45 & 66.45 \\
\hline $18: 00$ & 51.05 & 59.00 & 64.00 \\
\hline \multicolumn{4}{|c|}{ NOVEMBER } \\
\hline Time(hr) & $\mathrm{T}_{\mathrm{go}}\left({ }^{0} \mathrm{C}\right)$ & $\mathrm{T}_{\mathrm{gi}}\left({ }^{0} \mathrm{C}\right)$ & $\mathrm{T}_{\mathrm{w}}\left({ }^{0} \mathrm{C}\right)$ \\
\hline 07:00 & 19.85 & 20.95 & 25.00 \\
\hline 08:00 & 21.00 & 23.45 & 28.75 \\
\hline 09:00 & 23.45 & 27.00 & 30.45 \\
\hline $10: 00$ & 27.90 & 30.90 & 36.00 \\
\hline $11: 00$ & 30.90 & 35.75 & 43.05 \\
\hline $12: 00$ & 30.00 & 40.65 & 49.75 \\
\hline $13: 00$ & 34.05 & 43.60 & 58.65 \\
\hline $14: 00$ & 40.55 & 50.00 & 65.00 \\
\hline $15: 00$ & 46.70 & 56.80 & 69.70 \\
\hline $16: 00$ & 49.95 & 59.10 & 70.00 \\
\hline $17: 00$ & 44.00 & 54.60 & 67.50 \\
\hline $18: 00$ & 41.05 & 50.00 & 61.00 \\
\hline \multicolumn{4}{|c|}{ DECEMBER } \\
\hline Time(hr) & $\mathrm{T}_{\mathrm{go}}\left({ }^{0} \mathrm{C}\right)$ & $\mathrm{T}_{\mathrm{gi}}\left({ }^{0} \mathrm{C}\right)$ & $\mathrm{T}_{\mathrm{w}}\left({ }^{0} \mathrm{C}\right)$ \\
\hline 07:00 & 17.95 & 19.00 & 24.00 \\
\hline 08:00 & 19.05 & 22.45 & 27.15 \\
\hline 09:00 & 21.75 & 26.05 & 29.00 \\
\hline $10: 00$ & 26.40 & 29.75 & 33.75 \\
\hline $11: 00$ & 29.80 & 32.00 & 36.00 \\
\hline $12: 00$ & 34.15 & 38.80 & 39.40 \\
\hline $13: 00$ & 38.10 & 41.40 & 40.55 \\
\hline $14: 00$ & 41.00 & 49.00 & 46.05 \\
\hline $15: 00$ & 43.85 & 56.00 & 50.00 \\
\hline $16: 00$ & 47.55 & 53.65 & 54.70 \\
\hline $17: 00$ & 43.95 & 49.00 & 50.00 \\
\hline 18:00 & 40.00 & 46.15 & 49.00 \\
\hline \multicolumn{4}{|c|}{ OCTOBER } \\
\hline Time(hr) & $\mathrm{T}_{\mathrm{go}}\left({ }^{0} \mathrm{C}\right)$ & $\mathrm{T}_{\mathrm{gi}}\left({ }^{0} \mathrm{C}\right)$ & $\mathrm{T}_{\mathrm{w}}\left({ }^{\circ} \mathrm{C}\right)$ \\
\hline 07:00 & 19.85 & 20.85 & 25.45 \\
\hline 08:00 & 20.05 & 22.45 & 27.05 \\
\hline 09:00 & 24.15 & 28.00 & 38.65 \\
\hline $10: 00$ & 29.05 & 34.15 & 43.75 \\
\hline $11: 00$ & 35.00 & 39.05 & 45.80 \\
\hline $12: 00$ & 38.95 & 44.15 & 50.00 \\
\hline $13: 00$ & 47.00 & 50.50 & 56.45 \\
\hline $14: 00$ & 47.80 & 54.75 & 61.05 \\
\hline $15: 00$ & 53.00 & 61.00 & 68.75 \\
\hline $16: 00$ & 59.00 & 66.75 & 74.00 \\
\hline $17: 00$ & 58.05 & 64.00 & 70.50 \\
\hline $18: 00$ & 51.45 & 61.85 & 65.75 \\
\hline
\end{tabular}




\begin{tabular}{|c|c|c|c|}
\hline \multicolumn{4}{|c|}{ NOVEMBER } \\
\hline Time(hr) & $\mathrm{T}_{\mathrm{go}}\left({ }^{\circ} \mathrm{C}\right)$ & $\mathrm{T}_{\mathrm{gi}}\left({ }^{0} \mathrm{C}\right)$ & $\mathrm{T}_{\mathrm{w}}\left({ }^{0} \mathrm{C}\right)$ \\
\hline 07:00 & 19.85 & 20.95 & 25.00 \\
\hline 08:00 & 21.00 & 23.45 & 28.75 \\
\hline 09:00 & 23.45 & 27.00 & 30.45 \\
\hline $10: 00$ & 27.90 & 30.90 & 36.00 \\
\hline $11: 00$ & 30.90 & 35.75 & 43.05 \\
\hline $12: 00$ & 30.00 & 40.65 & 49.75 \\
\hline $13: 00$ & 34.05 & 43.60 & 58.65 \\
\hline $14: 00$ & 40.55 & 50.00 & 65.00 \\
\hline $15: 00$ & 46.70 & 56.80 & 69.70 \\
\hline $16: 00$ & 49.95 & 59.10 & 70.00 \\
\hline $17: 00$ & 44.00 & 54.60 & 67.50 \\
\hline 18:00 & 41.05 & 50.00 & 61.00 \\
\hline \multicolumn{4}{|c|}{ DECEMBER } \\
\hline Time(hr) & $\mathrm{T}_{\mathrm{go}}\left({ }^{0} \mathrm{C}\right)$ & $\mathrm{T}_{\mathrm{gi}}\left({ }^{0} \mathrm{C}\right)$ & $T_{w}\left({ }^{0} C\right)$ \\
\hline 07:00 & 17.95 & 19.00 & 24.00 \\
\hline 08:00 & 19.05 & 22.45 & 27.15 \\
\hline 09:00 & 21.75 & 26.05 & 29.00 \\
\hline $10: 00$ & 26.40 & 29.75 & 33.75 \\
\hline $11: 00$ & 29.80 & 32.00 & 36.00 \\
\hline $12: 00$ & 34.15 & 38.80 & 39.40 \\
\hline $13: 00$ & 38.10 & 41.40 & 40.55 \\
\hline $14: 00$ & 41.00 & 49.00 & 46.05 \\
\hline $15: 00$ & 43.85 & 56.00 & 50.00 \\
\hline $16: 00$ & 47.55 & 53.65 & 54.70 \\
\hline $17: 00$ & 43.95 & 49.00 & 50.00 \\
\hline $18: 00$ & 40.00 & 46.15 & 49.00 \\
\hline
\end{tabular}

Table 1: Hourly Average Outer Glass Temperature, Inner Glass Temperature and Temperature of Water for Various Hours of the Working Days for May To December, 2015

\begin{tabular}{|c|c|c|c|c|c|c|c|c|c|}
\hline $\begin{array}{l}\text { Time } \\
\text { (hrs) }\end{array}$ & $\begin{array}{c}h_{r, w-g} \\
\left(\frac{w}{m^{2} K}\right) \times 10^{-5}\end{array}$ & $\begin{array}{l}h_{e, w-g} \\
\left(\frac{W}{m^{2} K}\right)\end{array}$ & $\begin{array}{c}\boldsymbol{h}_{c, w-g} \\
\left(\frac{W}{m^{2} K}\right)\end{array}$ & $\begin{array}{c}\boldsymbol{h}_{t, w-g} \\
\left(\frac{W}{m^{2} K}\right)\end{array}$ & $\begin{array}{c}\boldsymbol{h}_{r, g-a} \\
\left(\frac{W}{m^{2} K}\right)\end{array}$ & $\begin{array}{c}\boldsymbol{h}_{c, g-a} \\
\left(\frac{W}{m^{2} K}\right)\end{array}$ & $\begin{array}{c}\boldsymbol{h}_{t, g-a} \\
\left(\frac{W}{m^{2} K}\right)\end{array}$ & $\begin{array}{c}U_{w o} \\
\left(\frac{W}{m^{2} K}\right)\end{array}$ & $\begin{array}{c}U_{t} \\
\left(\frac{W}{m^{2} K}\right)\end{array}$ \\
\hline 07:00 & 1.52 & 0.020 & 1.57 & 1.59 & 433.21 & 7.21 & 440.42 & 0.68 & 1.59 \\
\hline 08:00 & 1.53 & 0.021 & 1.60 & 1.62 & 512.98 & 6.79 & 519.77 & 0.66 & 1.62 \\
\hline 09:00 & 1.55 & 0.022 & 1.66 & 1.68 & 222.42 & 6.10 & 228.52 & 0.64 & 1.68 \\
\hline $10: 00$ & 1.58 & 0.023 & 1.77 & 1.79 & 272.07 & 10.99 & 283.06 & 0.61 & 1.79 \\
\hline $11: 00$ & 1.61 & 0.024 & 1.87 & 1.89 & 164.07 & 8.35 & 172.42 & 0.58 & 1.88 \\
\hline $12: 00$ & 1.64 & 0.025 & 1.89 & 1.92 & 158.79 & 8.50 & 167.29 & 0.57 & 1.91 \\
\hline $13: 00$ & 1.67 & 0.025 & 1.91 & 1.94 & 87.24 & 5.41 & 92.65 & 0.56 & 1.93 \\
\hline $14: 00$ & 1.69 & 0.026 & 1.97 & 2.00 & 63.85 & 5.74 & 69.59 & 0.55 & 1.98 \\
\hline $15: 00$ & 1.72 & 0.027 & 2.06 & 2.09 & 44.22 & 8.14 & 52.99 & 0.53 & 2.07 \\
\hline $16: 00$ & 1.71 & 0.024 & 1.87 & 1.89 & 43.97 & 8.77 & 52.96 & 0.58 & 1.87 \\
\hline $17: 00$ & 1.71 & 0.022 & 1.70 & 1.72 & 50.16 & 5.80 & 55.96 & 0.63 & 1.70 \\
\hline 18:00 & 1.67 & 0.024 & 0.86 & 1.88 & 59.00 & 9.85 & 68.85 & 0.58 & 1.86 \\
\hline
\end{tabular}

Table 2: Radiative, Convective, Evaporative, Total Heat Transfer Coefficients from Water to Glass and from Glass to Air with the Total and Overall Top Loss Coefficients of the Working Days of the Months July, 2015 


\begin{tabular}{|c|c|c|c|c|c|c|c|c|c|}
\hline $\begin{array}{l}\text { Time } \\
\text { (Hrs) }\end{array}$ & $\begin{array}{c}\mathbf{h}_{\mathrm{r}, \mathrm{w}-\mathrm{g}} \\
\left(\frac{\mathrm{w}}{\mathbf{m}^{2} \mathrm{~K}}\right) \times 10^{-5}\end{array}$ & $\begin{array}{l}\mathbf{h}_{\mathrm{e}, \mathrm{w}-\mathrm{g}} \\
\left(\frac{\mathbf{W}}{\mathbf{m}^{2} \mathbf{K}}\right)\end{array}$ & $\begin{array}{l}\mathbf{h}_{\mathbf{c , w}-\mathrm{g}} \\
\left(\frac{\mathrm{W}}{\mathbf{m}^{2} \mathbf{K}}\right)\end{array}$ & $\begin{array}{l}\mathbf{h}_{\mathrm{t}, \mathrm{w}-\mathrm{g}} \\
\left(\frac{\mathrm{W}}{\mathbf{m}^{2} \mathbf{K}}\right)\end{array}$ & $\begin{array}{c}\mathbf{h}_{\mathbf{r}, \mathbf{g}-\mathbf{a}} \\
\left(\frac{\mathbf{W}}{\mathbf{m}^{2} \mathbf{K}}\right)\end{array}$ & $\begin{array}{l}\mathbf{h}_{\mathbf{c , g}-\mathbf{a}} \\
\left(\frac{\stackrel{W}{W}}{\mathbf{m}^{2} \mathbf{K}}\right)\end{array}$ & $\begin{array}{c}\mathbf{h}_{\mathrm{t}, \mathbf{g}-\mathbf{a}} \\
\left(\frac{\mathbf{W}}{\mathbf{m}^{2} \mathbf{K}}\right)\end{array}$ & $\begin{array}{c}\mathbf{U}_{\mathbf{w o}} \\
\left(\frac{\mathbf{W}^{2}}{\mathbf{m}^{2} \mathbf{K}}\right)\end{array}$ & $\begin{array}{c}\mathbf{U}_{\mathrm{t}} \\
\left(\frac{\mathbf{W}}{\mathbf{m}^{2} \mathbf{K}}\right)\end{array}$ \\
\hline 07:00 & 1.52 & 0.025 & 1.90 & 1.93 & 289.45 & 5.02 & 294.47 & 0.57 & 1.98 \\
\hline 08:00 & 1.53 & 0.025 & 1.95 & 1.98 & 413.17 & 8.74 & 421.91 & 0.55 & 1.98 \\
\hline 09:00 & 1.55 & 0.028 & 2.16 & 2.19 & 210.76 & 5.77 & 216.53 & 0.50 & 2.18 \\
\hline $10: 00$ & 1.58 & 0.031 & 2.41 & 2.44 & 222.62 & 6.19 & 228.81 & 0.46 & 2.44 \\
\hline $11: 00$ & 1.61 & 0.031 & 2.39 & 2.42 & 119.25 & 8.83 & 128.08 & 0.46 & 2.41 \\
\hline $12: 00$ & 1.64 & 0.034 & 2.58 & 2.61 & 109.36 & 7.03 & 116.39 & 0.43 & 2.60 \\
\hline $13: 00$ & 1.67 & 0.035 & 2.67 & 2.71 & 71.26 & 10.15 & 81.41 & 0.42 & 2.70 \\
\hline $14: 00$ & 1.69 & 0.027 & 2.10 & 2.13 & 58.55 & 7.12 & 65.67 & 0.52 & 2.11 \\
\hline $15: 00$ & 1.72 & 0.026 & 1.99 & 2.02 & 62.09 & 4.60 & 66.67 & 0.54 & 2.00 \\
\hline $16: 00$ & 1.71 & 0.025 & 1.94 & 1.97 & 31.47 & 7.09 & 38.56 & 0.55 & 1.94 \\
\hline $17: 00$ & 1.70 & 0.024 & 1.82 & 1.84 & 36.71 & 7.97 & 44.70 & 0.59 & 1.82 \\
\hline $18: 00$ & 1.67 & 0.011 & 0.82 & 0.87 & 46.34 & 9.85 & 56.19 & 1.17 & 0.85 \\
\hline
\end{tabular}

Table 3: Radiative, Convective, Evaporative, Total Heat Transfer Coefficients from Water to Glass and From Glass to Air with the Total and Overall Top Loss Coefficients of the Working Days of the Months June, 2015

\begin{tabular}{|c|c|c|c|c|c|c|c|c|c|}
\hline $\begin{array}{l}\text { Time } \\
\text { (Hrs) }\end{array}$ & $\begin{array}{c}\boldsymbol{h}_{r, w-g} \\
\left(\frac{w}{m^{2} K}\right) X 10^{-5}\end{array}$ & $\begin{array}{l}\boldsymbol{h}_{e, w-g} \\
\left(\frac{W}{m^{2} K}\right)\end{array}$ & $\begin{array}{c}\boldsymbol{h}_{c, w-g} \\
\left(\frac{W}{m^{2} K}\right)\end{array}$ & $\begin{array}{l}h_{t, w-g} \\
\left(\frac{W}{m^{2} K}\right)\end{array}$ & $\begin{array}{c}\boldsymbol{h}_{r, g-a} \\
\left(\frac{W}{m^{2} K}\right)\end{array}$ & $\begin{array}{l}h_{c, g-a} \\
\left(\frac{W}{m^{2} K}\right)\end{array}$ & $\begin{array}{c}\boldsymbol{h}_{t, g-a} \\
\left(\frac{W}{m^{2} K}\right)\end{array}$ & $\begin{array}{c}U_{w o} \\
\left(\frac{W}{m^{2} K}\right)\end{array}$ & $\left(\frac{U_{t}}{W}\right)$ \\
\hline 07:00 & 1.52 & 0.020 & 1.57 & 1.59 & 433.21 & 7.21 & 440.42 & 0.68 & 1.59 \\
\hline $08: 00$ & 1.53 & 0.021 & 1.60 & 1.62 & 512.98 & 6.79 & 519.77 & 0.66 & 1.62 \\
\hline 09:00 & 1.55 & 0.022 & 1.66 & 1.68 & 222.42 & 6.10 & 228.52 & 0.64 & 1.68 \\
\hline $10: 00$ & 1.58 & 0.023 & 1.77 & 1.79 & 272.07 & 10.99 & 283.06 & 0.61 & 1.79 \\
\hline $11: 00$ & 1.61 & 0.024 & 1.87 & 1.89 & 164.07 & 8.35 & 172.42 & 0.58 & 1.88 \\
\hline $12: 00$ & 1.64 & 0.025 & 1.89 & 1.92 & 158.79 & 8.50 & 167.29 & 0.57 & 1.91 \\
\hline $13: 00$ & 1.67 & 0.025 & 1.91 & 1.94 & 87.24 & 5.41 & 92.65 & 0.56 & 1.93 \\
\hline $14: 00$ & 1.69 & 0.026 & 1.97 & 2.00 & 63.85 & 5.74 & 69.59 & 0.55 & 1.98 \\
\hline $15: 00$ & 1.72 & 0.027 & 2.06 & 2.09 & 44.22 & 8.14 & 52.99 & 0.53 & 2.07 \\
\hline $16: 00$ & 1.71 & 0.024 & 1.87 & 1.89 & 43.97 & 8.77 & 52.96 & 0.58 & 1.87 \\
\hline $17: 00$ & 1.71 & 0.022 & 1.70 & 1.72 & 50.16 & 5.80 & 55.96 & 0.63 & 1.70 \\
\hline $18: 00$ & 1.67 & 0.024 & 0.86 & 1.88 & 59.00 & 9.85 & 68.85 & 0.58 & 1.86 \\
\hline
\end{tabular}

Table 4: Radiative, Convective, Evaporative, Total Heat Transfer Coefficients from Water to Glass and From Glass to Air with the Total and Overall Top Loss Coefficients of the Working Days of the Months September, 2015

\begin{tabular}{|c|c|c|c|c|c|c|c|c|c|}
\hline $\begin{array}{l}\text { Time } \\
(\text { Hrs })\end{array}$ & $\begin{array}{c}h_{r, w-g} \\
\left(\frac{w}{m^{2} K}\right) X 10^{-5}\end{array}$ & $\begin{array}{l}\boldsymbol{h}_{e, w-g} \\
\left(\frac{W}{m^{2} K}\right)\end{array}$ & $\begin{array}{c}\boldsymbol{h}_{c, w-g} \\
\left(\frac{W}{m^{2} K}\right)\end{array}$ & $\begin{array}{l}\boldsymbol{h}_{t, w-g} \\
\left(\frac{W}{m^{2} K}\right)\end{array}$ & $\begin{array}{c}\boldsymbol{h}_{r, g-a} \\
\left(\frac{W}{m^{2} K}\right)\end{array}$ & $\begin{array}{l}h_{c, g-a} \\
\left(\frac{W}{m^{2} K}\right)\end{array}$ & $\begin{array}{c}\boldsymbol{h}_{t, g-a} \\
\left(\frac{W}{m^{2} K}\right)\end{array}$ & $\begin{array}{c}U_{w o} \\
\left(\frac{W}{m^{2} K}\right)\end{array}$ & $\begin{array}{c}U_{t} \\
\left(\frac{W}{m^{2} K}\right) \\
\end{array}$ \\
\hline $07: 00$ & 1.51 & 0.023 & 1.74 & 1.76 & 484.19 & 5.80 & 489.99 & 0.62 & 1.76 \\
\hline 08:00 & 1.52 & 0.024 & 1.81 & 1.83 & 420.40 & 8.05 & 428.45 & 0.59 & 1.83 \\
\hline 09:00 & 1.54 & 0.024 & 1.81 & 1.83 & 316.37 & 5.47 & 321.84 & 0.59 & 1.83 \\
\hline $10: 00$ & 1.56 & 0.022 & 1.72 & 1.74 & 193.78 & 9.22 & 203.00 & 0.62 & 1.73 \\
\hline $11: 00$ & 1.59 & 0.023 & 1.79 & 1.81 & 182.46 & 11.80 & 194.26 & 0.60 & 1.80 \\
\hline $12: 00$ & 1.61 & 0.024 & 1.81 & 1.83 & 101.73 & 8.74 & 101.73 & 0.59 & 1.83 \\
\hline $13: 00$ & 1.63 & 0.024 & 1.82 & 1.84 & 78.35 & 8.80 & 78.35 & 0.59 & 1.83 \\
\hline $14: 00$ & 1.65 & 0.025 & 1.90 & 1.93 & 60.79 & 5.74 & 60.79 & 0.57 & 1.91 \\
\hline $15: 00$ & 1.67 & 0.027 & 2.09 & 2.12 & 51.76 & 7.12 & 51.76 & 0.52 & 2.10 \\
\hline $16: 00$ & 1.70 & 0.025 & 1.93 & 1.96 & 45.45 & 5.86 & 45.45 & 0.56 & 1.94 \\
\hline $17: 00$ & 1.67 & 0.024 & 1.84 & 1.86 & 45.71 & 9.31 & 45.71 & 0.58 & 1.84 \\
\hline 18:00 & 1.66 & 0.022 & 1.70 & 1.72 & 49.66 & 8.77 & 49.66 & 0.63 & 1.70 \\
\hline
\end{tabular}

Table 5: Radiative, Convective, Evaporative, Total Heat Transfer Coefficients from Water to Glass and From Glass to Air with the Total and Overall Top Loss Coefficients of the Working Days of the Months August, 2015 


\begin{tabular}{|c|c|c|c|c|c|c|c|c|c|}
\hline $\begin{array}{c}\text { Time } \\
\text { (hrs) }\end{array}$ & $\begin{array}{c}\boldsymbol{h}_{\boldsymbol{r}, \boldsymbol{w}-\boldsymbol{g}} \\
\left(\frac{\boldsymbol{W}}{\boldsymbol{m}^{2} \boldsymbol{K}}\right) \mathbf{x} 10^{-5}\end{array}$ & $\begin{array}{c}\boldsymbol{h}_{\boldsymbol{e}, \boldsymbol{w}-\boldsymbol{g}} \\
\left(\frac{\boldsymbol{W}}{\boldsymbol{m}^{2} \boldsymbol{K}}\right)\end{array}$ & $\begin{array}{c}\boldsymbol{h}_{\boldsymbol{c , w - g}-\boldsymbol{g}} \\
\left(\frac{\boldsymbol{W}}{\boldsymbol{m}^{2} \boldsymbol{K}}\right)\end{array}$ & $\begin{array}{c}\boldsymbol{h}_{\boldsymbol{t}, \boldsymbol{w}-\boldsymbol{g}} \\
\left(\frac{\boldsymbol{W}}{\boldsymbol{m}^{2} \boldsymbol{K}}\right)\end{array}$ & $\begin{array}{c}\boldsymbol{h}_{\boldsymbol{r}, \boldsymbol{g}-\boldsymbol{a}} \\
\left(\frac{\boldsymbol{W}}{\boldsymbol{m}^{2} \boldsymbol{K}}\right)\end{array}$ & $\begin{array}{c}\boldsymbol{h}_{\boldsymbol{c}, \boldsymbol{g}-\boldsymbol{a}} \\
\left(\frac{\boldsymbol{W}}{\boldsymbol{m}^{2} \boldsymbol{K}}\right)\end{array}$ & $\begin{array}{c}\boldsymbol{h}_{\boldsymbol{t , g - a}} \\
\left(\frac{\boldsymbol{W}}{\boldsymbol{m}^{2} \boldsymbol{K}}\right)\end{array}$ & $\begin{array}{c}\boldsymbol{U}_{\boldsymbol{w o}} \\
\left(\frac{\boldsymbol{W}}{\boldsymbol{m}^{2} \boldsymbol{K}}\right)\end{array}$ & $\begin{array}{c}\boldsymbol{U}_{\boldsymbol{t}} \\
\left(\frac{\boldsymbol{W}}{\boldsymbol{m}^{2} \boldsymbol{K}}\right.\end{array}$ \\
\hline $07: 00$ & 1.50 & 0.016 & 1.24 & 1.26 & 433.21 & 5.74 & 438.95 & 0.84 & 1.26 \\
\hline $08: 00$ & 1.52 & 0.018 & 1.40 & 1.42 & 373.38 & 8.05 & 381.43 & 0.75 & 1.42 \\
\hline $09: 00$ & 1.53 & 0.015 & 1.15 & 1.17 & 350.59 & 8.95 & 359.54 & 0.90 & 1.17 \\
\hline $10: 00$ & 1.56 & 0.018 & 1.38 & 1.40 & 281.25 & 8.50 & 289.75 & 0.76 & 1.40 \\
\hline $11: 00$ & 1.59 & 0.019 & 1.43 & 1.45 & 294.47 & 7.75 & 302.15 & 0.74 & 1.45 \\
\hline $12: 00$ & 1.62 & 0.021 & 1.59 & 1.61 & 328.34 & 5.95 & 334.29 & 0.67 & 1.61 \\
\hline $13: 00$ & 1.65 & 0.022 & 1.66 & 1.68 & 228.53 & 5.20 & 233.73 & 0.64 & 1.68 \\
\hline $14: 00$ & 1.68 & 0.022 & 1.73 & 1.75 & 145.05 & 8.05 & 153.10 & 0.62 & 1.74 \\
\hline $15: 00$ & 1.71 & 0.022 & 1.68 & 1.70 & 68.93 & 9.13 & 78.06 & 0.64 & 1.69 \\
\hline $16: 00$ & 1.71 & 0.021 & 1.61 & 1.63 & 49.32 & 5.50 & 54.82 & 0.66 & 1.61 \\
\hline $17: 00$ & 1.70 & 0.022 & 1.69 & 1.71 & 70.89 & 5.80 & 76.69 & 0.63 & 1.70 \\
\hline $18: 00$ & 1.67 & 0.024 & 1.88 & 1.90 & 76.16 & 6.20 & 82.39 & 0.57 & 1.89 \\
\hline
\end{tabular}

Table 6: Radiative, Convective, Evaporative, Total Heat Transfer Coefficients from Water to Glass and From Glass to Air with the Total and Overall Top Loss Coefficients of the Working Days of the Months November, 2015

\begin{tabular}{|c|c|c|c|c|c|c|c|c|c|}
\hline $\begin{array}{l}\text { Time } \\
\text { (hrs) }\end{array}$ & $\begin{array}{c}\boldsymbol{h}_{r, w-g} \\
\left(\frac{W}{m^{2} K}\right) \times 10^{-5}\end{array}$ & $\begin{array}{l}h_{e, w-g} \\
\left(\frac{W}{m^{2} K}\right)\end{array}$ & $\begin{array}{l}h_{c, w-g} \\
\left(\frac{W}{m^{2} K}\right)\end{array}$ & $\begin{array}{l}h_{t, w-g} \\
\left(\frac{W}{m^{2} K}\right)\end{array}$ & $\begin{array}{c}\boldsymbol{h}_{\boldsymbol{r}, \boldsymbol{g}-\boldsymbol{a}} \\
\left(\frac{W}{\boldsymbol{m}^{2} K}\right)\end{array}$ & $\begin{array}{l}h_{c, g-a} \\
\left(\frac{W}{m^{2} K}\right)\end{array}$ & $\begin{array}{c}\boldsymbol{h}_{t, g-a} \\
\left(\frac{W}{m^{2} K}\right)\end{array}$ & $\left(\frac{{ }_{W o}^{W}}{m^{2} K}\right)$ & $\left(\begin{array}{l}U_{t} \\
m^{2} K\end{array}\right)$ \\
\hline 07:00 & 1.49 & 0.018 & 1.36 & 1.38 & 241.13 & 5.74 & 246.18 & 0.77 & 1.38 \\
\hline 08:00 & 1.51 & 0.017 & 1.33 & 1.35 & 664.78 & 8.05 & 670.22 & 0.79 & 1.35 \\
\hline 09:00 & 1.54 & 0.016 & 1.26 & 1.28 & 278.17 & 8.95 & 286.22 & 0.83 & 1.28 \\
\hline $10: 00$ & 1.55 & 0.016 & 1.24 & 1.26 & 257.49 & 8.50 & 267.64 & 0.84 & 1.26 \\
\hline $11: 00$ & 1.56 & 0.017 & 1.28 & 1.30 & 188.35 & 7.75 & 197.15 & 0.82 & 1.29 \\
\hline $12: 00$ & 1.58 & 0.017 & 1.30 & 1.32 & 120.74 & 5.95 & 129.39 & 0.80 & 1.31 \\
\hline $13: 00$ & 1.61 & 0.017 & 1.33 & 1.35 & 110.17 & 5.20 & 115.97 & 0.79 & 1.34 \\
\hline $14: 00$ & 1.64 & 0.018 & 1.36 & 1.38 & 81.14 & 8.05 & 89.79 & 0.77 & 1.37 \\
\hline $15: 00$ & 1.68 & 0.018 & 1.38 & 1.40 & 55.07 & 9.13 & 64.96 & 0.76 & 1.38 \\
\hline $16: 00$ & 1.66 & 0.017 & 1.31 & 1.33 & 51.07 & 5.50 & 61.22 & 0.80 & 1.31 \\
\hline $17: 00$ & 1.64 & 0.016 & 1.25 & 1.27 & 58.60 & 5.80 & 64.73 & 0.83 & 1.25 \\
\hline $18: 00$ & 1.63 & 0.014 & 1.05 & 1.06 & 59.30 & 6.28 & 64.35 & 0.99 & 1.04 \\
\hline
\end{tabular}

Table 7: Radiative, Convective, Evaporative, Total Heat Transfer Coefficients from Water to Glass and From Glass to Air with the Total and Overall Top Loss Coefficients of the Working Days of the Months December, 2015

\begin{tabular}{|c|c|c|c|}
\hline \multicolumn{4}{|c|}{ MAY } \\
\hline Time(hr) & $\mathbf{T}_{\text {inw }}\left({ }^{0} \mathrm{C}\right)$ & $\mathbf{T}_{\text {outw }}\left({ }^{0} \mathrm{C}\right)$ & $\mathbf{T}_{\text {flatp }}\left({ }^{0} \mathrm{C}\right)$ \\
\hline 07:00 & 19.00 & 37.15 & 47.45 \\
\hline 08:00 & 21.75 & 48.20 & 62.30 \\
\hline 09:00 & 23.00 & 53.75 & 69.15 \\
\hline $10: 00$ & 26.00 & 64.20 & 77.20 \\
\hline $11: 00$ & 28.15 & 96.05 & 118.90 \\
\hline $12: 00$ & 30.00 & 109.25 & 138.30 \\
\hline $13: 00$ & 31.55 & 129.00 & 157.00 \\
\hline $14: 00$ & 34.05 & 156.00 & 176.65 \\
\hline $15: 00$ & 32.70 & 145.15 & 215.90 \\
\hline $16: 00$ & 30.80 & 139.00 & 202.95 \\
\hline $17: 00$ & 29.05 & 125.95 & 177.25 \\
\hline $18: 00$ & 26.85 & 114.50 & 159.90 \\
\hline \multicolumn{4}{|c|}{ JUNE } \\
\hline Time(hr) & $\mathrm{T}_{\mathrm{inw}}\left({ }^{0} \mathrm{C}\right)$ & $\mathrm{T}_{\text {outw }}\left({ }^{0} \mathrm{C}\right)$ & $\mathrm{T}_{\text {flatp }}\left({ }^{0} \mathrm{C}\right)$ \\
\hline 07:00 & 18.25 & 32.05 & 42.15 \\
\hline 08:00 & 19.70 & 35.00 & 49.25 \\
\hline 09:00 & 21.75 & 43.15 & 57.75 \\
\hline $10: 00$ & 23.00 & 51.00 & 66.20 \\
\hline $11: 00$ & 27.15 & 64.95 & 96.45 \\
\hline $12: 00$ & 30.25 & 73.30 & 113.25 \\
\hline $13: 00$ & 31.60 & 91.00 & 131.65 \\
\hline $14: 00$ & 34.05 & 129.35 & 156.50 \\
\hline $15: 00$ & 32.00 & 113.00 & 145.05 \\
\hline
\end{tabular}




\begin{tabular}{|c|c|c|c|}
\hline $16: 00$ & 30.90 & 109.85 & 130.00 \\
\hline $17: 00$ & 28.75 & 97.25 & 117.95 \\
\hline 18:00 & 27.05 & 86.00 & 109.50 \\
\hline \multicolumn{4}{|c|}{ JULY } \\
\hline Time(hr) & $\mathbf{T}_{\text {inw }}\left({ }^{0} \mathrm{C}\right)$ & $\mathbf{T}_{\text {outw }}\left({ }^{0} \mathbf{C}\right)$ & $\mathbf{T}_{\text {flatp }}\left({ }^{0} \mathrm{C}\right)$ \\
\hline 07:00 & 17.25 & 29.35 & 37.05 \\
\hline 08:00 & 18.00 & 30.05 & 42.75 \\
\hline 09:00 & 20.05 & 45.85 & 52.55 \\
\hline $10: 00$ & 22.25 & 49.00 & 64.00 \\
\hline $11: 00$ & 25.55 & 57.95 & 75.05 \\
\hline $12: 00$ & 26.75 & 59.35 & 101.25 \\
\hline $13: 00$ & 27.00 & 89.00 & 119.65 \\
\hline $14: 00$ & 29.15 & 107.35 & 134.00 \\
\hline $15: 00$ & 28.00 & 111.00 & 133.25 \\
\hline $16: 00$ & 28.35 & 102.00 & 126.00 \\
\hline $17: 00$ & 28.00 & 95.20 & 114.55 \\
\hline $18: 00$ & 27.65 & 84.55 & 102.00 \\
\hline \multicolumn{4}{|c|}{ AUGUST } \\
\hline Time(hr) & $\mathbf{T}_{\text {inw }}\left({ }^{0} \mathrm{C}\right)$ & $\mathbf{T}_{\text {outw }}\left({ }^{0} \mathrm{C}\right)$ & $\mathrm{T}_{\text {flatp }}\left({ }^{0} \mathrm{C}\right)$ \\
\hline 07:00 & 16.95 & 27.55 & 34.55 \\
\hline 08:00 & 17.00 & 28.15 & 40.85 \\
\hline 09:00 & 19.85 & 40.75 & 51.55 \\
\hline $10: 00$ & 20.25 & 44.90 & 57.95 \\
\hline 11:00 & 23.55 & 47.05 & 68.45 \\
\hline $12: 00$ & 26.75 & 60.85 & 93.85 \\
\hline $13: 00$ & 29.95 & 83.70 & 114.75 \\
\hline $14: 00$ & 29.75 & 103.55 & 129.50 \\
\hline $15: 00$ & 27.00 & 108.95 & 125.65 \\
\hline $16: 00$ & 28.05 & 103.95 & 121.00 \\
\hline $17: 00$ & 26.00 & 92.55 & 113.35 \\
\hline 18:00 & 25.65 & 77.00 & 92.95 \\
\hline \multicolumn{4}{|c|}{ SEPTEMBER } \\
\hline Time(hr) & $\mathbf{T}_{\mathrm{inw}}\left({ }^{0} \mathrm{C}\right)$ & $\mathbf{T}_{\text {outw }}\left({ }^{\circ} \mathrm{C}\right)$ & $\mathrm{T}_{\text {flatp }}\left({ }^{0} \mathrm{C}\right)$ \\
\hline 07:00 & 16.95 & 24.15 & 33.55 \\
\hline 08:00 & 17.00 & 25.95 & 36.95 \\
\hline 09:00 & 19.85 & 36.65 & 48.05 \\
\hline $10: 00$ & 20.25 & 43.00 & 52.95 \\
\hline $11: 00$ & 23.55 & 40.95 & 62.95 \\
\hline $12: 00$ & 26.75 & 46.35 & 81.75 \\
\hline $13: 00$ & 29.95 & 79.75 & 116.65 \\
\hline $14: 00$ & 29.75 & 98.55 & 122.00 \\
\hline $15: 00$ & 27.00 & 106.00 & 113.65 \\
\hline $16: 00$ & 28.05 & 101.05 & 112.30 \\
\hline $17: 00$ & 26.00 & 86.55 & 109.25 \\
\hline $18: 00$ & 25.65 & 76.00 & 92.05 \\
\hline \multicolumn{4}{|c|}{ OCTOBER } \\
\hline Time(hr) & $\mathbf{T}_{\mathrm{inw}}\left({ }^{0} \mathrm{C}\right)$ & $\mathbf{T}_{\text {outw }}\left({ }^{0} \mathrm{C}\right)$ & $\mathrm{T}_{\text {flatp }}\left({ }^{0} \mathrm{C}\right)$ \\
\hline 07:00 & 17.00 & 24.05 & 33.05 \\
\hline 08:00 & 17.45 & 24.75 & 39.55 \\
\hline 09:00 & 19.05 & 38.05 & 50.05 \\
\hline $10: 00$ & 20.25 & 40.00 & 59.05 \\
\hline $11: 00$ & 24.90 & 44.15 & 68.45 \\
\hline $12: 00$ & 26.85 & 60.95 & 89.00 \\
\hline $13: 00$ & 27.95 & 84.75 & 114.75 \\
\hline $14: 00$ & 29.75 & 102.65 & 131.00 \\
\hline $15: 00$ & 28.75 & 108.00 & 124.75 \\
\hline $16: 00$ & 27.05 & 103.05 & 113.00 \\
\hline $17: 00$ & 26.65 & 93.55 & 108.85 \\
\hline $18: 00$ & 25.00 & 77.30 & 96.05 \\
\hline
\end{tabular}




\begin{tabular}{|c|c|c|c|}
\hline \multicolumn{4}{|c|}{ NOVEMBER } \\
\hline Time(hr) & $\mathrm{T}_{\text {inw }}\left({ }^{0} \mathrm{C}\right)$ & $\mathbf{T}_{\text {outw }}\left({ }^{0} \mathrm{C}\right)$ & $\mathrm{T}_{\text {flatp }}\left({ }^{0} \mathrm{C}\right)$ \\
\hline 07:00 & 17.25 & 21.35 & 29.05 \\
\hline 08:00 & 18.00 & 22.05 & 34.75 \\
\hline 09:00 & 20.05 & 37.85 & 44.55 \\
\hline $10: 00$ & 22.25 & 41.00 & 56.00 \\
\hline $11: 00$ & 25.55 & 49.95 & 67.05 \\
\hline $12: 00$ & 26.75 & 35.35 & 93.25 \\
\hline $13: 00$ & 27.00 & 81.00 & 111.65 \\
\hline $14: 00$ & 29.15 & 99.35 & 126.00 \\
\hline $15: 00$ & 28.00 & 103.00 & 125.25 \\
\hline $16: 00$ & 28.35 & 94.00 & 118.00 \\
\hline $17: 00$ & 28.00 & 87.20 & 107.55 \\
\hline $18: 00$ & 27.65 & 76.55 & 96.00 \\
\hline \multicolumn{4}{|c|}{ DECEMBER } \\
\hline Time(hr) & $\mathbf{T}_{\text {inw }}\left({ }^{0} \mathrm{C}\right)$ & $\mathbf{T}_{\text {outw }}\left({ }^{0} \mathbf{C}\right)$ & $\mathbf{T}_{\text {flatp }}\left({ }^{0} \mathrm{C}\right)$ \\
\hline 07:00 & 16.95 & 18.15 & 25.85 \\
\hline 08:00 & 17.00 & 19.95 & 28.05 \\
\hline 09:00 & 19.85 & 30.65 & 35.05 \\
\hline $10: 00$ & 20.25 & 37.00 & 43.95 \\
\hline $11: 00$ & 23.55 & 34.95 & 55.95 \\
\hline $12: 00$ & 26.75 & 40.35 & 85.00 \\
\hline $13: 00$ & 29.95 & 73.75 & 99.00 \\
\hline $14: 00$ & 29.75 & 92.55 & 118.00 \\
\hline $15: 00$ & 27.00 & 100.00 & 116.95 \\
\hline $16: 00$ & 28.05 & 95.05 & 109.30 \\
\hline $17: 00$ & 26.00 & 80.55 & 100.00 \\
\hline $18: 00$ & 25.65 & 70.00 & 95.85 \\
\hline
\end{tabular}

Table 8: Performance Parameters of Solar Collector Panel from May to December, 2015

\begin{tabular}{|c|c|c|c|c|c|c|c|c|}
\hline $\begin{array}{c}\text { Time } \\
\text { (hr) }\end{array}$ & $\begin{array}{c}\text { May } \\
(\text { Lit } / \boldsymbol{h r})\end{array}$ & $\begin{array}{c}\text { June } \\
(\text { Lit/hr) }\end{array}$ & $\begin{array}{c}\text { July } \\
(\text { Lit/hr) }\end{array}$ & $\begin{array}{c}\text { Aug. } \\
(\text { Lit/hr })\end{array}$ & $\begin{array}{c}\text { Sept. } \\
(\text { Lit/hr })\end{array}$ & $\begin{array}{c}\text { Oct. } \\
(\text { Lit } / h r)\end{array}$ & $\begin{array}{c}\text { Nov. } \\
(\text { Lit/hr })\end{array}$ & $\begin{array}{c}\text { Dec. } \\
(\text { Lit } / h r)\end{array}$ \\
\hline 07:00 & 12.6 & 10.1 & 5.1 & 2.8 & 1.8 & 2.0 & 2.9 & 1.8 \\
\hline 08:00 & 14.4 & 14.2 & 8.2 & 4.3 & 3.9 & 3.8 & 6.2 & 2.7 \\
\hline 09:00 & 17.8 & 17.3 & 10.3 & 6.2 & 5.4 & 6.2 & 9.3 & 4.0 \\
\hline $10: 00$ & 22.7 & 22.3 & 12.3 & 8.3 & 8.0 & 9.4 & 10.5 & 7.2 \\
\hline 11:00 & 26.2 & 24.7 & 15.4 & 11.4 & 9.7 & 13.3 & 14.6 & 10.2 \\
\hline $12: 00$ & 27.5 & 28.7 & 17.5 & 14.4 & 12.9 & 16.8 & 18.7 & 12.2 \\
\hline $13: 00$ & 30.2 & 26.8 & 20.6 & 17.5 & 16.5 & 14.8 & 15.6 & 15.3 \\
\hline $14: 00$ & 28.1 & 22.7 & 16.6 & 15.4 & 14.7 & 11.3 & 12.5 & 11.3 \\
\hline $15: 00$ & 25.0 & 18.6 & 14.4 & 12.3 & 11.8 & 8.2 & 9.7 & 8.4 \\
\hline $16: 00$ & 21.7 & 15.5 & 10.3 & 10.2 & 8.7 & 6.0 & 7.9 & 6.3 \\
\hline $17: 00$ & 17.8 & 13.3 & 8.3 & 8.0 & 6.2 & 4.7 & 6.0 & 5.1 \\
\hline 18:00 & 15.0 & 11.7 & 7.9 & 5.9 & 4.9 & 3.0 & 5.9 & 0.60 \\
\hline Total & 259.0 & 226.0 & 146.9 & 116.7 & 104.5 & 109.8 & 119.8 & 79.5 \\
\hline
\end{tabular}

Table 9: Hourly Total Productivity Values Per Week of the Working Days of the Months (May - December) 2015

\begin{tabular}{|c|c|c|c|c|c|c|c|c|}
\hline $\begin{array}{c}\text { Time } \\
\text { (hr) }\end{array}$ & $\begin{array}{c}\text { May } \\
\mathbf{W} / \boldsymbol{m}^{2}\end{array}$ & $\begin{array}{c}\text { June } \\
\mathrm{W} / \boldsymbol{m}^{2}\end{array}$ & $\begin{array}{c}\text { July } \\
\text { W/m }\end{array}$ & $\begin{array}{c}\text { Aug. } \\
\mathrm{W} / \boldsymbol{m}^{2}\end{array}$ & $\begin{array}{c}\text { Sept. } \\
\mathrm{W} / \boldsymbol{m}^{2}\end{array}$ & $\begin{array}{c}\text { Oct. } \\
\mathrm{W} / \boldsymbol{m}^{2}\end{array}$ & $\begin{array}{c}\text { Nov. } \\
\text { W/m }\end{array}$ & $\begin{array}{c}\text { Dec. } \\
\mathrm{W} / \boldsymbol{m}^{2}\end{array}$ \\
\hline 07:00 & 217.0 & 215.8 & 132.8 & 120.2 & 117.0 & 124.6 & 116.6 & 106.2 \\
\hline 08:00 & 296.4 & 230.0 & 147.0 & 139.0 & 134.2 & 139.0 & 133.8 & 133.0 \\
\hline 09:00 & 348.2 & 248.4 & 178.2 & 157.2 & 158.8 & 148.8 & 159.6 & 134.0 \\
\hline 10:00 & 398.0 & 379.0 & 210.2 & 171.0 & 177.4 & 159.4 & 176.6 & 152.6 \\
\hline $11: 00$ & 452.2 & 410.0 & 273.0 & 190.0 & 189.8 & 188.0 & 188.6 & 154.4 \\
\hline 12:00 & 477.2 & 459.4 & 347.0 & 220.8 & 210.2 & 219.0 & 208.2 & 206.6 \\
\hline $13: 00$ & 455.0 & 437.6 & 294.2 & 242.4 & 236.6 & 245.1 & 235.2 & 242.2 \\
\hline $14: 00$ & 433.3 & 399.0 & 267.0 & 224.4 & 229.4 & 236.6 & 227.8 & 226.6 \\
\hline $15: 00$ & 367.6 & 350.6 & 241.2 & 211.0 & 207.8 & 186.8 & 206.0 & 192.0 \\
\hline 16:00 & 296.0 & 301.0 & 201.0 & 197.0 & 179.2 & 179.4 & 178.8 & 175.8 \\
\hline $17: 00$ & 203.6 & 261.0 & 169.2 & 167.2 & 152.4 & 168.6 & 151.2 & 160.6 \\
\hline 18:00 & 180.8 & 212.8 & 149.0 & 139.4 & 131.4 & 142.6 & 130.6 & 140.4 \\
\hline Average & 316.4 & 292.13 & 217.48 & 181.63 & 177.02 & 178.016 & 176.08 & 168.70 \\
\hline
\end{tabular}




\begin{tabular}{|c|c|c|c|c|}
\hline Months & $\begin{array}{c}\text { Total } \\
\text { Productivity } \\
(\boldsymbol{L i t} / \boldsymbol{h} \boldsymbol{r})\end{array}$ & $\begin{array}{c}\text { Average daily } \\
\text { solar Radiation } \\
\mathbf{W} / \mathbf{m}^{\mathbf{2}}\end{array}$ & $\begin{array}{c}\text { Efficiency } \\
\text { of solar Still } \\
(\%)\end{array}$ & $\begin{array}{c}\text { Efficiency } \\
\text { of Flat Plate (\%) }\end{array}$ \\
\hline May & 259.0 & 316.40 & 83.73 & 69.35 \\
\hline June & 226.0 & 292.13 & 78.84 & 60.81 \\
\hline July & 146.9 & 217.48 & 68.84 & 60.87 \\
\hline August & 116.7 & 181.63 & 65.48 & 59.46 \\
\hline September & 104.5 & 172.02 & 60.16 & 55.26 \\
\hline October & 99.5 & 178.16 & 62.81 & 56.83 \\
\hline November & 119.8 & 176.08 & 69.34 & 51.27 \\
\hline December & 79.5 & 168.70 & 48.03 & 47.51 \\
\hline
\end{tabular}

Table 11: Hourly Average Efficiency Values of Solar Collector Panel of the Working Days of the Months (May - December) 2015

\begin{tabular}{|c|c|c|c|c|c|c|c|c|}
\hline \multirow{2}{*}{$\begin{array}{c}\text { Time } \\
\text { (hr) }\end{array}$} & \multicolumn{2}{|c|}{ MAY } & \multicolumn{2}{|c|}{ JUNE } & \multicolumn{2}{|c|}{ JULY } & \multicolumn{2}{|c|}{ AUGUST } \\
\hline & $\mathrm{T}_{\mathrm{amb}}\left({ }^{0} \mathrm{C}\right)$ & $\mathrm{V}\left(\mathbf{m s ^ { - 1 }}\right)$ & $\mathrm{T}_{\mathrm{amb}}\left({ }^{0} \mathrm{C}\right)$ & $\mathrm{V}\left(\mathbf{m s}^{-\mathbf{1}}\right)$ & $\mathrm{T}_{\mathrm{amb}}\left({ }^{0} \mathrm{C}\right)$ & $\mathrm{V}\left(\mathbf{m s}^{-1}\right)$ & $\mathrm{T}_{\mathrm{amb}}\left({ }^{0} \mathrm{C}\right)$ & $\mathrm{V}\left(\mathbf{m} \mathbf{s}^{-\mathbf{1}}\right)$ \\
\hline 07:00 & 19.95 & 2.32 & 19.25 & 2.74 & 18.15 & 3.47 & 17.25 & 2.00 \\
\hline 08:00 & 23.85 & 3.95 & 22.70 & 4.98 & 19.00 & 3.33 & 18.05 & 3.75 \\
\hline 09:00 & 27.45 & 2.11 & 25.05 & 2.99 & 21.25 & 2.10 & 20.00 & 3.89 \\
\hline $10: 00$ & 28.25 & 4.45 & 27.25 & 3.13 & 25.00 & 2.73 & 23.30 & 2.14 \\
\hline $11: 00$ & 30.05 & 3.00 & 27.55 & 2.01 & 27.15 & 4.85 & 25.45 & 3.00 \\
\hline 12:00 & 30.60 & 2.21 & 29.75 & 3.38 & 31.35 & 3.90 & 28.05 & 2.98 \\
\hline $13: 00$ & 33.05 & 4.73 & 30.00 & 3.41 & 33.00 & 3.87 & 30.00 & 2.00 \\
\hline $14: 00$ & 38.15 & 3.00 & 32.15 & 2.45 & 34.05 & 2.98 & 31.05 & 4.98 \\
\hline $15: 00$ & 36.35 & 2.98 & 36.55 & 2.44 & 32.55 & 2.78 & 30.85 & 2.44 \\
\hline $16: 00$ & 35.35 & 2.12 & 33.35 & 3.67 & 30.00 & 4.99 & 29.20 & 2.02 \\
\hline $17: 00$ & 34.20 & 2.62 & 32.00 & 4.43 & 30.65 & 3.00 & 27.65 & 2.17 \\
\hline 18:00 & 30.65 & 3.89 & 29.65 & 3.73 & 29.00 & 2.35 & 25.95 & 3.99 \\
\hline
\end{tabular}

Table 12: Total Monthly Productivity and Solar Radiation with the Efficiency of the Solar Still and Solar Collector Panel for Various Months (May - December)

\begin{tabular}{|c|c|c|c|c|c|c|c|c|}
\hline \multirow{2}{*}{$\begin{array}{c}\text { Time } \\
(\mathrm{hr})\end{array}$} & \multicolumn{2}{|c|}{ September } & \multicolumn{2}{|c|}{ October } & \multicolumn{2}{|c|}{ November } & \multicolumn{2}{|c|}{ December } \\
\hline & $\mathrm{T}_{\mathrm{amb}}\left({ }^{0} \mathrm{C}\right)$ & $V\left(\mathbf{m s}^{-1}\right)$ & $\mathrm{T}_{\mathrm{amb}}\left({ }^{0} \mathrm{C}\right)$ & $\mathrm{V}\left(\mathrm{ms}^{-1}\right)$ & $\mathrm{T}_{\mathrm{amb}}\left({ }^{0} \mathrm{C}\right)$ & $\mathrm{V}\left(\mathrm{ms}^{-1}\right)$ & $\mathrm{T}_{\mathrm{amb}}\left({ }^{0} \mathrm{C}\right)$ & $\mathrm{V}\left(\mathrm{ms}^{-1}\right)$ \\
\hline $07: 00$ & 19.95 & 3.32 & 19.25 & 3.74 & 18.15 & 4.47 & 17.25 & 4.00 \\
\hline 08:00 & 23.85 & 2.95 & 22.70 & 2.98 & 19.00 & 3.33 & 18.05 & 3.75 \\
\hline 09:00 & 27.45 & 2.11 & 25.05 & 4.99 & 21.25 & 3.10 & 20.00 & 2.89 \\
\hline $10: 00$ & 28.25 & 3.45 & 27.25 & 3.13 & 25.00 & 2.73 & 23.30 & 2.14 \\
\hline 11:00 & 30.05 & 4.00 & 27.55 & 2.01 & 27.15 & 4.85 & 25.45 & 3.00 \\
\hline $12: 00$ & 30.60 & 4.21 & 29.75 & 2.38 & 31.35 & 4.90 & 28.05 & 2.98 \\
\hline 13:00 & 33.05 & 2.73 & 30.00 & 2.41 & 33.00 & 4.87 & 30.00 & 2.00 \\
\hline $14: 00$ & 38.15 & 3.00 & 32.15 & 2.45 & 34.05 & 3.98 & 31.05 & 2.98 \\
\hline $15: 00$ & 36.35 & 2.98 & 36.55 & 3.44 & 32.55 & 2.78 & 30.85 & 4.44 \\
\hline $16: 00$ & 35.35 & 4.12 & 33.35 & 4.67 & 30.00 & 3.99 & 29.20 & 2.02 \\
\hline $17: 00$ & 34.20 & 3.62 & 32.00 & 3.43 & 30.65 & 3.00 & 27.65 & 2.17 \\
\hline $18: 00$ & 30.65 & 3.89 & 29.65 & 4.73 & 29.00 & 2.35 & 25.95 & 2.99 \\
\hline
\end{tabular}

Table 13: Data for Ambient Temperature and Wind Speed for the Month of May to December (Adamawa State University, Mubi, Adamawa State Nigeria Meteorological Station, 2015) 


\begin{tabular}{|c|c|c|c|c|c|c|c|c|}
\hline $\begin{array}{c}\text { Time } \\
\mathbf{( H r})\end{array}$ & $\begin{array}{c}\mathbf{M a y} \\
\mathbf{W} / \mathbf{m}^{\mathbf{2}}\end{array}$ & $\begin{array}{c}\text { June } \\
\mathbf{W} / \mathbf{m}^{\mathbf{2}}\end{array}$ & $\begin{array}{c}\mathbf{J u l y} \\
\mathbf{W} / \mathbf{m}^{2}\end{array}$ & $\begin{array}{c}\text { Aug. } \\
\mathbf{W} / \mathbf{m}^{2}\end{array}$ & $\begin{array}{c}\text { Sept. } \\
\mathbf{W} / \mathbf{m}^{2}\end{array}$ & $\begin{array}{c}\mathbf{0 c t .} \\
\mathbf{W} / \mathbf{m}^{2}\end{array}$ & $\begin{array}{c}\text { Nov. } \\
\mathbf{W} / \mathbf{m}^{2}\end{array}$ & $\begin{array}{c}\text { Dec. } \\
\mathbf{W} / \mathbf{m}^{\mathbf{2}}\end{array}$ \\
\hline $07: 00$ & 217.0 & 215.8 & 132.8 & 120.2 & 117.0 & 124.6 & 116.6 & 106.2 \\
\hline $08: 00$ & 296.4 & 230.0 & 147.0 & 139.0 & 134.2 & 139.0 & 133.8 & 133.0 \\
\hline $09: 00$ & 348.2 & 248.4 & 178.2 & 157.2 & 158.8 & 148.8 & 159.6 & 134.0 \\
\hline $10: 00$ & 398.0 & 379.0 & 210.2 & 171.0 & 177.4 & 159.4 & 176.6 & 152.6 \\
\hline $11: 00$ & 452.2 & 410.0 & 273.0 & 190.0 & 189.8 & 188.0 & 188.6 & 154.4 \\
\hline $12: 00$ & 477.2 & 459.4 & 347.0 & 220.8 & 210.2 & 219.0 & 208.2 & 206.6 \\
\hline $13: 00$ & 455.0 & 437.6 & 294.2 & 242.4 & 236.6 & 245.1 & 235.2 & 242.2 \\
\hline $14: 00$ & 433.3 & 399.0 & 267.0 & 224.4 & 229.4 & 236.6 & 227.8 & 226.6 \\
\hline $15: 00$ & 367.6 & 350.6 & 241.2 & 211.0 & 207.8 & 186.8 & 206.0 & 192.0 \\
\hline $16: 00$ & 296.0 & 301.0 & 201.0 & 197.0 & 179.2 & 179.4 & 178.8 & 175.8 \\
\hline $17: 00$ & 203.6 & 261.0 & 169.2 & 167.2 & 152.4 & 168.6 & 151.2 & 160.6 \\
\hline $18: 00$ & 180.8 & 212.8 & 149.0 & 139.4 & 131.4 & 142.6 & 130.6 & 140.4 \\
\hline Average & $\mathbf{3 1 6 . 4}$ & $\mathbf{2 9 2 . 1 3}$ & $\mathbf{2 1 7 . 4 8}$ & $\mathbf{1 8 1 . 6 3}$ & $\mathbf{1 7 7 . 0 2}$ & $\mathbf{1 7 8 . 0 1 6}$ & $\mathbf{1 7 6 . 0 8}$ & $\mathbf{1 6 8 . 7 0}$ \\
\hline
\end{tabular}

Table 14: Data for Mean Monthly Global Solar Radiation for Various Hours of the Working Days for May to December (Adamawa State University, Mubi, Adamawa State Nigeria Meteorological Station, 2015)

\subsection{Calculation of the Overall Top Loss Coefficient from Water to Atmosphere}

The radiative heat transfer coefficient of water to glass for the experimental period displayed in Table 2 has been calculated using equation 2.7 for May, 2015 at 15:00pm as shown below

$\varepsilon_{f f}=\frac{1}{\left(\frac{1}{0.93}+\frac{1}{0.96}\right)-1}=0.895$

$h_{r, w-g}=0.895 \times 5.67 \times 10^{-8}\left[\frac{(94.35+273)^{2}+(68.95+273)^{2}}{94.35+68.95+546}\right]=1.98 \times 10^{-5} W^{-2} K^{-1}$

The convective heat transfer coefficient of water to glass for the experimental period displayed in Table 2 has been calculated using equation 2.10 for May, 2015 at 15:00pm as shown below

$$
\begin{aligned}
& P_{w}=\exp ^{\left(25.317-\frac{5144}{273+94.35}\right)}=81961.56 \mathrm{Nm}^{-2} \\
& P_{g i}=\exp ^{\left(25.317-\frac{5144}{273+68.95}\right)}=28965.62 \mathrm{Nm}^{-2} \\
& \Delta T=(94.35-68.95)+\left[\frac{(81961.56-28965.62)+(81961.56+273)}{268.9 \times 10^{-3}-81961.56}\right]=23.75^{0} \mathrm{C} \\
& h_{c, w-g}=0.884[23.75]^{\frac{1}{3}}=2.54 \mathrm{Wm}^{-2} \mathrm{~K}^{-1}
\end{aligned}
$$

The evaporative heat transfer coefficient of water to glass for the experimental period displayed in Table 2 has been calculated using equation 2.12 for May, 2015 at 15:00pm as shown below

$h_{e, w-g}=0.013 \times 2.54=0.033 W^{-2} K^{-1}$

The heat transfer coefficient of water to glass for the experimental period displayed in Table 2 has been calculated using equation 2.13 for May, 2015 at 15:00pm as shown below

$h_{t, w-g}=2.54+0.033+1.98 \times 10^{-5}=2.57 \mathrm{Wm}^{-2} \mathrm{~K}^{-1}$

The radiative heat transfer coefficient of glass to atmosphere for the experimental period displayed in Table 2 has been calculated using equation 2.16 for May, 2015 at 15:00pm as shown below

$T_{\text {sky }}=36.35-6=30.36^{\circ} \mathrm{C}$

$h_{r, g-a}=0.93 \times 5.67 \times 10^{-8}\left[\frac{(60.75+273)^{4}+(30.35+273)^{4}}{60.75-36.35}\right]=45.11 W^{-2} K^{-1}$

The convective heat transfer coefficient of glass to atmosphere for the experimental period displayed in Table 2 has been calculated using equation 2.17 for May, 2015 at 15:00pm as shown below

$h_{c, g-a}=2.8+(3.0 \times 2.98)=11.74 \mathrm{Wm}^{-2} K^{-1}$

The total to heat transfer coefficient of glass to atmosphere for the experimental period displayed in Table 2 has been calculated using equation 2.14 for May, 2015 at 15:00pm as shown below

$h_{t, g-a}=45.11+11.74=56.85 \mathrm{Wm}^{-2} \mathrm{~K}^{-1}$

The total internal to heat loss transfer coefficient and conductive coefficient of glass for the experimental period displayed in Table 2 has been calculated using equation 2.18 for May, 2015 at 15:00pm as shown below

$U_{w o}=\left(\frac{1}{2.57}+\frac{0.04}{0.85}\right)=0.48 \mathrm{Wm}^{-2} K^{-1}$

The overall top loss coefficient from water to atmosphere for the experimental period displayed in Table 9 has been calculated using equation 2.14 for May, 2015 at 15:00pm as shown below

$U_{t}=\frac{2.57 \times 56.85}{56.85+0.48}=2.55 \mathrm{Wm}^{-2} \mathrm{~K}^{-1}$ 
4.3. Calculation of the Efficiency of the Solar Distillation

The overall efficiency of the solar distillation for the experimental period displayed in Table 13 has been calculated using equation 2.20 for May, 2015 as shown below

$\eta=\left(\frac{259.0 \times 2260}{316.40 \times 0.616 \times 3600}\right) \times 100 \%=83.34 \%$

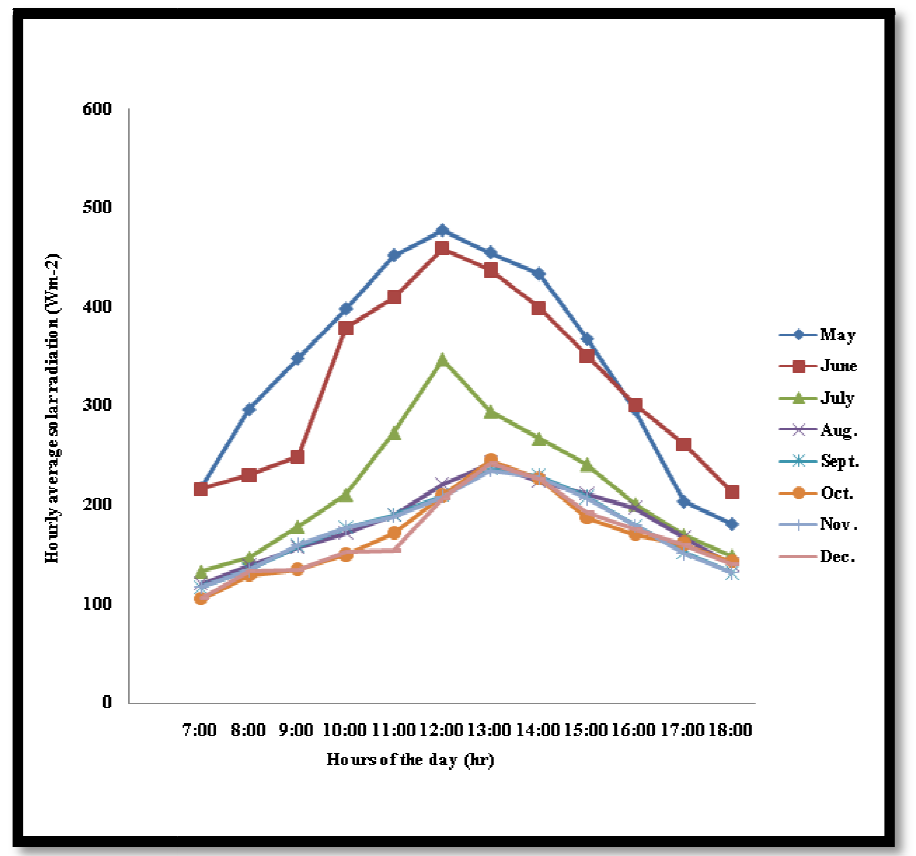

Figure 10: Hourly Average Solar Radiation for Various Hours of the Working Days for the Months of May to December, 2015

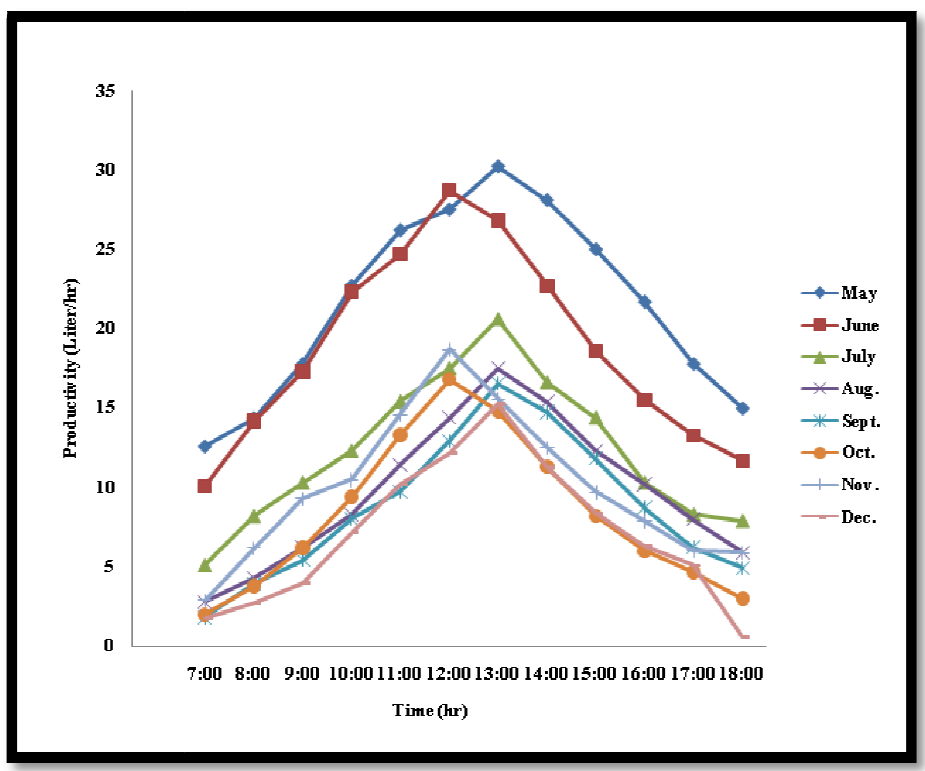

Figure 11: Total Productivity for Various Hours of the Working Day for the Months of May to December 


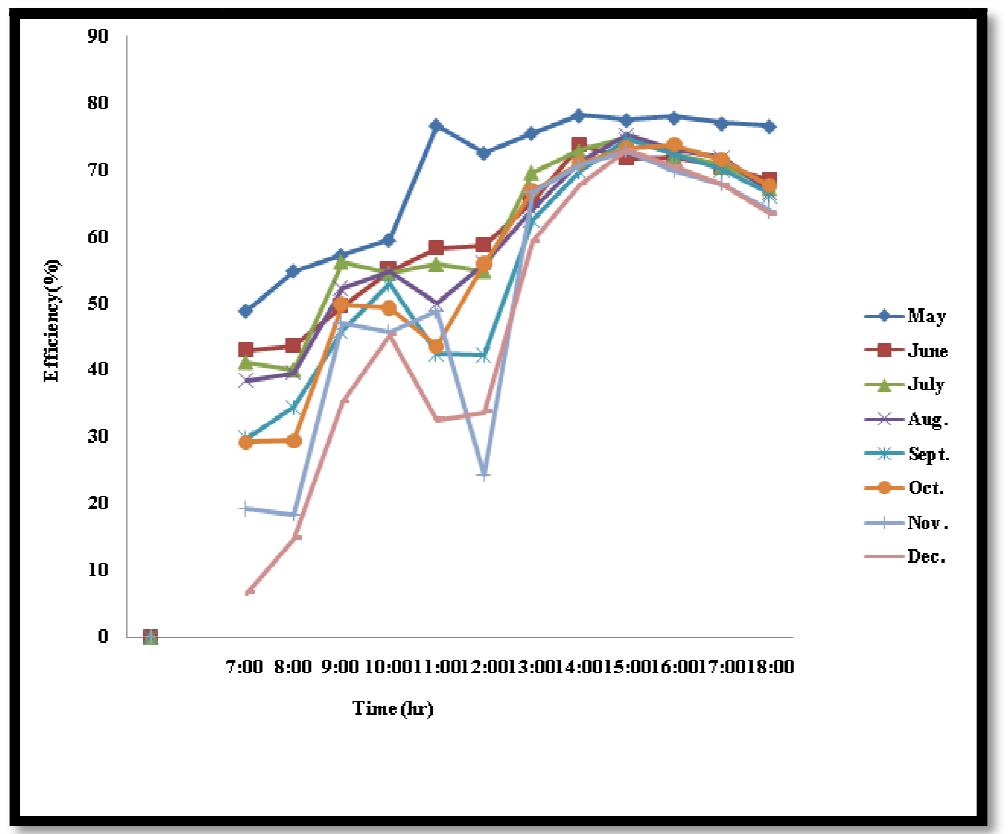

Figure 12: Daily Average Efficiency of the Solar Collector Panel for Various Hours of the Working Day for the Months of May to December, 2015

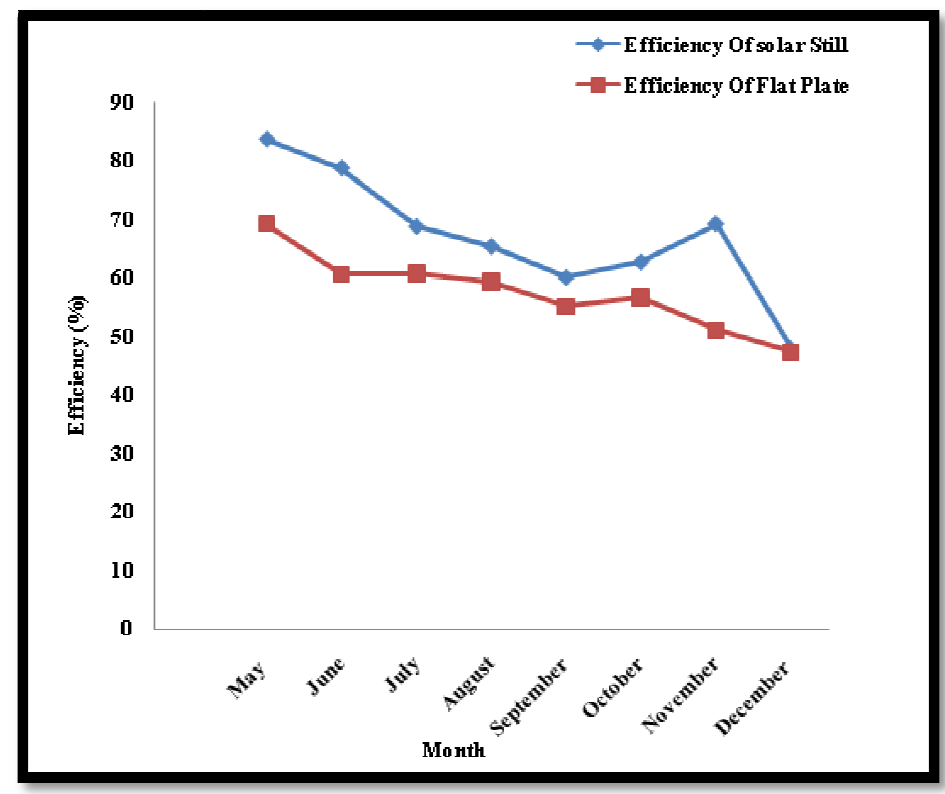

Figure 13: Efficiency of Solar Still and That of the Solar Collector Panel for Various Months of (May to December) of the Year, 2015

\subsection{Discussions of Results}

Table 10 summarized the hourly average solar radiation values during the typical day for different months May to December of the year 2015. The Table revealed that the average daily solar radiation values for the month of May, June, July, August, September, October, November, and December were $316.40 \mathrm{Wm}^{-2}, 292.13 \mathrm{Wm}^{-2}, 217.48 \mathrm{Wm}^{-2}, 181.63 \mathrm{Wm}^{-2}$, $172.02 \mathrm{Wm}^{-2}, 178.16 \mathrm{Wm}^{-2}, 176.08 \mathrm{Wm}^{-2}$ and $168.70 \mathrm{Wm}^{-2}$, respectively. The daily solar radiation value during the month of October and November was greater than the month of September because during the working days of the month of September there was abruption by the clouds and heavy rainfall, while the days were clear during the month of October and November. The effective day length for the months of May to December was 12 hours.

Figure 4.1 showed the hourly average solar radiation for various hours of the typical days for the months of May to December, 2015. It was revealed from the graph that every month had different maximum solar radiation values and different day lengths, descending from the month of May to December. The overlapping occurs due to seasonal changes like clouds, haze, and light and heavy rainfall in weather, the maximum hourly solar radiation value achieved was 477.2 $\mathrm{Wm}^{-2}$ during 12:00-13:00 hours in the month of May then descending from 459.4Wm ${ }^{-2}$ in June, $347.0 \mathrm{Wm} \mathrm{Ju}^{-2}$ in $\mathrm{July}$ $242.4 \mathrm{Wm}^{-2}$ in August, $236.6 \mathrm{Wm}^{-2}$ in September, $245.1 \mathrm{Wm}^{-2}$ in 0ctober, $235.2 \mathrm{Wm}^{-2}$ in November and $242.2 \mathrm{Wm}{ }^{-2}$ in December. The day length of the month was also maximum in May and minimum in December.

Table 11 presented the hourly total productivity values of the solar still for working day of different months (May to December) of the year 2015. The table also revealed that, by summing up these hourly values of the productivity of solar still, we may obtain the total productivity values for the months (May to December) of the year 2015. This could be seen in 
the last row of the Table 11 The values for May, June, July, August, September, October, November, and December were $259.00 \mathrm{lit} / \mathrm{hr}, 226.00 \mathrm{lit} / \mathrm{hr}, 146.90 \mathrm{lit} / \mathrm{hr}, 116.70 \mathrm{lit} / \mathrm{hr}, 104.50 \mathrm{lit} / \mathrm{hr}, 109.80 \mathrm{lit} / \mathrm{hr}, 119.80 \mathrm{lit} / \mathrm{hr} \mathrm{and} 79.50 \mathrm{lit} / \mathrm{hr}$ respectively.

The output during the month of November was greater than the month of October because relatively more solar radiation was received during the working days of the month of November.

Figure 4.2 represents the total productivity for various hours of the working days for the months of May to December, 2015. It was revealed from the Figure that the productivity was mainly dependent and directly proportional to the solar radiation, day length, ambient temperature and internal temperature of the still. The maximum hourly productivity gained was 30.20 liters at 13:00hours in the month of May, $28.70 \mathrm{lit} / \mathrm{hr}$ at 12:00hours in June, 20.60 lit/hr at 13:00hours in July, $16.50 \mathrm{lit} / \mathrm{hr}$ at 13:00hours in September, 16.8liters at 12:00hours in October, 18.70 lit/hr at 12:00hours in November and minimum, $14.40 \mathrm{lit} / \mathrm{hr}$ at 13:00hours in August and 15.30 lit/hr at 12:00hours in December. As the trend of the curves shows that there was maximum quantity of output during the month of May because the month of June received the maximum clear sky solar radiation intensity, ambient temperature, and the maximum day length during the working days.

Figure 4.3 showed the hourly average efficiency of the solar collector panel for various hours of the working days for the months of May to December, 2015. It was revealed from the graph that every month had different maximum efficiency values and different day lengths, descending from the month of May to December. The overlapping occurs due to seasonal changes like clouds, haze, and light and heavy rainfall in weather, the maximum efficiency obtain is in the month of May while the minimum is in the month of December.

The efficiency of the solar still and that of the solar collector panel for various months (May- December) is shown in Table 13. The efficiency for the solar still was calculated by using equation 2.20 by considering the total productivity, average solar radiation incident during the time period of a day, the area of the solar still basin $0.616 \mathrm{~m}^{2}$ and the value of latent heat of vaporization $(2260 \mathrm{~kJ} /$ litre $)$.

The efficiency of the solar still and solar collector panel was greater during the month of May $(83.73 \%$ and $69.35 \%$ respectively) and fell down for the remaining months; however, the efficiency was also better for the months of November and December than September and October. This was because of better productivity output in response of solar radiation values during these months. The solar still gave an average productivity of 143.99 liters/hrs and average efficiency of $66.80 \%$ for eight months of the year 2015.

The trend of the efficiency curves for various months of the year, 2015 is presented in Figure 4.4. It is clear from the graph that the maximum efficiency was during the month of May, then lowered down for the months of July, August, up to September then increased again for the months of October, November, and December, showing that the productivity was better in response of solar radiation during these months.

\section{Summary, Conclusion and Recommendations}

\subsection{Summary}

An improved solar still for the production of pure water was design, constructed, and tested for this research work. The system used a separated storage (feed water tank) to collector (distilled water collector tank). In system an extra thermal energy (solar collector panel) is constructed to produce hot water that is feed into the basin to increase the rate of evaporation. Both numerical and experimental methods are use in the analysis for the optimum performance of the system. The result shows that the average productivity of solar still from May to December was 143.99 liters/hour at $213.45 \mathrm{Wm}^{-2}$ average daily solar radiation and the overall efficiency of the solar still was $67.15 \%$. This research work has demonstrated that solar water distillation system can be adopted to meet the drinking water need of a typical household and laboratory users.

\subsection{Conclusion}

The following conclusion are obtained from this research work

- The total daily productivity of solar still during typical days of the months of May, June, July, August, September, October, November and December were 259.0 liters/hr, 226.0 liters/hr, 146.9 liters/hr, 114.7 liters/hr, 104.5 liters/hr, 109.8 liters/hr, 119.8 liters/hr and 79.5 liters/hr, respectively.

- The average efficiency of the solar still and that of the solar collector panel for the months of June to December, 2015 was $67.15 \%$ and $57.67 \%$ respectively.

- The productivity of the solar still increased with the intensity of solar radiation and energy gained from the solar radiation inside the solar still.

- The productivity of the solar still also increased with the greater ambient temperature and longer day length.

\subsection{Recommendation}

The following can be observed for the improvement of this research work.

- The solar still of $0.25 \mathrm{~m}^{3}$ volume and basin area of $0.616 \mathrm{~m}^{2}$ under the climatic conditions of Mubi, was unable to produce the required amount of distillate, which could fulfill the drinking water requirement of a 3-4 members family. So, it was recommended that area of the solar still should be at least doubled, to get the required amount of distillate. 
- The solar still was made with the wood and get affected by rainfall and termite. Therefore; it was recommended that the solar still should be made with stainless steel material to avoid effect termite, rusting and corrosion. It would increase the cost but it will also increase the life of the solar still.

- The solar still should have proper insulation, so that the internal heat of the system could not escape through the body of the system by convection. Consequently, proper insulation of the solar still helped to improve the efficiency of the solar still.

\subsection{Contribution to Knowledge}

Many households especially in the rural areas struggle to meet their clean water need. The use of conventional energy sources to deliver hot water has adverse environmental impact like greenhouse emission, and acid rain. These energy alternatives are scarce, costly, and non-renewable in nature. Hence, the present work contributes knowledge on how to design and construction solar still for production of pure water. It is the simplest and the cheapest distillation system that can easily adopted for house use especially in the rural areas.

\section{References}

i. Areola,M. (1978). Environmental and Ecological Changes. Geojournal 3 (8) pp. 116 - 119.

ii. Christopher, A. \&Homola, P. E. (1990). 'Solar Domestic Hot Water Heating System: Design, Installation and Maintenances'. The Florida Solar Energy Centre.253-261

iii. Cornet S. (2001). How to Book: How to make a solar water distiller. Project Manager for EI Paso Solar Energy Association.

iv. Duffie, J.A. \& Beckman W.A., (1999): Solar Engineering of Thermal Processes. 3rd (ed). New Jersey: John Wiley and Sons, Inc.

v. Dunkle, R.V. (1961). Solar Water Distillation, the Roof Type Still and a Multiple Effect Diffusion Still, International Developments in Heat Transfer, ASME, Proceeding of International Heat Transfer, Part V, p 895 University of Colorado.

vi. Feilizadeh, M. Soltanieh, M. Jafarpur K. \&KarimiEstahbanati M.R. (2010).'A new radiation model for a single-slope solar still', Desalination, Vol. 262, pp. 166-173.

vii. Happer, G.D.J. (2007).Solar energy projects for the Evil Genius, Mc Grow Hill Coperations, pp 59

viii. Howell \&Buckius (1987).Fundamentals of Engineering Thermodynamics. McGraw-Hill, New York.pp 456-459

ix. Ihalawela P.H.C.A.\&Careem M.A. (2007).A Cheap Automatic Solar Water Distiller, 'Proceedings of the Technical Sessions 23', pp 41-45. Institute of Physics, Sri Lanka

x. Medugu D. W. \&Malgwi D. I.(2006)Design and Development of Solar Still for Effectiveness in Eliminating Microbial Contamination and Salt. Nigerian Journal of Physics. 18(2), $203-209$.

xi. Medugu D. W. \&Ndatuwong,L.G. (2009). Theoretical Analysis of Water Distillation using Solar Still. International Journal of Physical Sciences, 4(11), 705-712.

xii. Mendie, U.E. (2005). The theory and practices of clean water production for domestic and Industrial Use. Purified and packaged water, Lactomedals Publishers, pp. 51 - 104.

xiii. Nwokoye, A.O.C \&Laz, E. (2008). Green House Gases and Global Warming. Nigerian Journal of Physics, 20 (1), 76-83.

xiv. Omar O. B. and Mazen, M. A.(2007). Evaluating thermal performance of a single slope solar still. Heat Mass Transfer, Vol. 43, pp. 985-995.

xv. Rodrígueza, L.G.\&Camachob, C.G. (1999). Preliminary design and cost analysis of a solar distillation system, Solar Energy, 109-114

xvi. Rosemann N. (2009). Drinking Water Crisis in Pakistan and the Issue of Bottled Water. The Case of Nestlé's Pure Life. Action Aid Pakistan.

xvii. Sahoo. B. B. (2007): Performance Assessment of Solar Still Using Blackened Surface and Thermocole Insulation.

xviii. Sampathkumar, K. Arjunan, T.V. Pitchandi P. \&Senthilkumar, P. (2010). Active solar distillation - A detailed review, Renewable and Sustainable Energy Reviews, Vol. 14, 1503-1526.

xix. Singal, S. K, Varun, H .P \& Singh, R. P. (2007). Rural Electrification of a Remote Island by Renewable Energy Sources, International Journal of ScienceandTechnology, Vol 32, 2491 -2501.

xx. Speirs, R. (2007).Solar Distillers. http://www.Gomestic.com/Emergency-Preparation/Solar- Distillers.32567 $12 / 10 / 2008$.

xxi. Tiwari G.N. Dimri V, Singh U, Chel, A \& Sarkar B. (2007).Comparative Thermal Performance Evaluation of an Active Solar Distillation System. International Journal of Energy Research, Vol. 31, pp. 1465-1482.

xxii. Velmurugan, V \&Srithar, K. (2007).Solar stills integrated with a mini solar pond-] analytical simulation and experimental validation'. Desalination, Vol. 216, pp. 232-241.

xxiii. Walker A. (2007). National Renewable Laboratory Solar Water Heating. Canada. Retrieved from http://www.wbdg.org/design/swheating.php:on August 30, 2014. 